James Madison University

JMU Scholarly Commons

Libraries

Libraries

$5-31-2021$

\title{
Student Perceptions of Academic Librarians and the Librarian- Faculty-Student Dynamic: Minding our gaps
}

\author{
Lara Sapp \\ James Madison University, sapple@jmu.edu \\ Jody Fagan \\ James Madison University \\ Hillary Ostermiller \\ Columbia College Chicago, hostermiller@colum.edu \\ Elizabeth Price \\ James Madison University
}

Follow this and additional works at: https://commons.lib.jmu.edu/letfspubs

Part of the Library and Information Science Commons

\begin{abstract}
Recommended Citation
Jody Condit Fagan, Hillary Ostermiller, Elizabeth Price \& Lara Sapp (2021) Student Perceptions of Academic Librarians and the Librarian-Faculty-Student Dynamic: Minding our gaps DOI: 10.1080/ 13614533.2021.1906717
\end{abstract}

This Article is brought to you for free and open access by the Libraries at JMU Scholarly Commons. It has been accepted for inclusion in Libraries by an authorized administrator of JMU Scholarly Commons. For more information, please contact dc_admin@jmu.edu. 


\title{
Student Perceptions of Academic Librarians and the Librarian-Faculty- Student Dynamic: Minding our gaps
}

\author{
Jody Condit Fagan, Hillary Ostermiller, Elizabeth Price \& Lara Sapp \\ James Madison University \\ JMU Libraries, James Madison University, Harrisonburg, VA 22807 \\ faganjc@jmu.edu; hostermiller@colum.edu; price2el@jmu.edu; sapple@jimu.edu \\ Author Note \\ This is an Accepted Manuscript of an article published by Taylor \& Francis in the journal New \\ Review of Academic Librarianship on April 25, 2021, available online: \\ https:/www.tandfonline.com/doi/abs/10.1080/13614533.2021.1906717?.journalCode=racl20
}

p. 1 
A survey concerning perceptions of academic librarians was conducted at a large, 4-year university with three populations: librarians, faculty, and undergraduate students. This paper presents results from the student population, with comparison to the librarian and faculty samples. The major research questions address perceptions about what librarians know (expertise and skills), what librarians do (role and duties), and what librarians are like (motivations and affective characteristics). Respondents showed a little more awareness of librarians' professional duties than in previous studies; however, librarians' duties related to organization, reference, and teaching remained more hidden from view. And, many students still assume librarians do clerical work, and still underestimate librarians' salaries and required degrees. Most students still don't consult with librarians, as they do not believe librarians' help is needed by them - perhaps because they strongly associate librarians with books. Yet, students' value for librarians' expertise was high, and their value for librarians' knowledge and skill with resources rivalled that of faculty. Gaps among the three groups related to the definition of "research" seem important to address. The study also points to an ongoing need for research into specific populations of students, how prior experience affects college library use, and the potential for disciplinary differences among students.

Keywords: academic librarians, perceptions, stereotypes, faculty, college students, higher education 


\section{Introduction}

This is the fourth article in a series about the perceptions of academic librarians. The first article presented a literature review and study introduction (Fagan, et al., 2019a), the second presented results from the librarian sample (Fagan, et al., 2020b), the third presented results from the faculty sample (Fagan, et al., 2020c) and this article presents results from the student sample. For the purposes of this paper, "librarians" will be used to mean "academic librarians" since they were the subject of this survey.

Results will be compared with Hernon and Pastine (1977), Fagan (2003), and Bickley and Corrall (2011) where applicable (Table 1). This study's overall findings will be discussed in the context of these previous studies as well as the literature review (Fagan, et al., 2020a). 
Table 1. Previous studies concerning student perceptions.

\begin{tabular}{|c|c|c|c|}
\hline & Hernon and Pastine (1977) & Fagan (2003) & Bickley and Corall (2011) \\
\hline Study Design & $\begin{array}{l}\text { Conducted } 1975 \text { at } \\
\text { the University of } \\
\text { Nebraska,Omaha } \\
\text { Stratified sample of } \\
\text { full- time } \\
\text { undergraduates } \\
\text { Mailed paper surveys } \\
\text { with self-addressed, } \\
\text { stamped envelopes } \\
\text { Response rate of } \\
51.7 \%(n=362)\end{array}$ & $\begin{array}{l}\text { Conducted } 2001 \text { at } \\
\text { Southern Illinois } \\
\text { University } \\
\text { Carbondale A one- } \\
\text { credit library skills } \\
\text { class, given extra } \\
\text { creditPencil and } \\
\text { paper surveyhanded } \\
\text { out } \\
\text { Response rate } \\
\text { notreported ( } n= \\
48)\end{array}$ & $\begin{array}{l}\text { Conducted } 2010 \text { at } \\
\text { the University of } \\
\text { Sheffield Web-based } \\
\text { survey emailed to all } \\
\text { students Response } \\
\text { rate of } 1 \% \text { ( } n \\
=250 ; 129 \text { were } \\
\text { undergraduates) (p. } \\
230 \text { ) }\end{array}$ \\
\hline Overall Findings & $\begin{array}{l}\text { "Students generally } \\
\text { confuse the functions } \\
\text { and qualifications of } \\
\text { library staff and } \\
\text { perceivelibrarians as } \\
\text { service oriented and } \\
\text { as having less variety } \\
\text { of duties than they } \\
\text { actually have" (p. } \\
\text { 135). } \\
\text { "Students are, to a } \\
\text { greatextent, unaware } \\
\text { of educational } \\
\text { requirements and } \\
\text { capabilities of } \\
\text { librarians"(p. 136). } \\
\text { "Many students ... do } \\
\text { not fully utilize the } \\
\text { services, knowledge, } \\
\text { and expertise } \\
\text { provided by } \\
\text { librarians" (p. 136). } \\
\text { "Preoccupied, rude, } \\
\text { inconsiderate, and } \\
\text { discourteous service } \\
\text { were common } \\
\text { complaints... it } \\
\text { seems that library } \\
\text { personnel reinforce a } \\
\text { self-image of } \\
\text { inadequacy or } \\
\text { ignorance" (pp. 137- } \\
\text { 138). }\end{array}$ & $\begin{array}{l}\text { Students know } \\
\text { librariansare there to } \\
\text { help but often } \\
\text { consider librarians" } \\
\text { knowledge as limited } \\
\text { to the physical } \\
\text { library. } \\
\text { Described library } \\
\text { schooland librarian } \\
\text { expertise in } \\
\text { professional terms } \\
\text { and identified } \\
\text { librarians at SIUC as } \\
\text { faculty, "but their } \\
\text { descriptions of } \\
\text { librarians' job duties } \\
\text { included many } \\
\text { clerical tasks." } \\
\text { Students "are not } \\
\text { aware of librarians' } \\
\text { educational } \\
\text { background and the } \\
\text { professional character } \\
\text { ofa librarian's job." } \\
\text { "Students are aware } \\
\text { of the increase of } \\
\text { technology in libraries } \\
\text { and of librarians' } \\
\text { positiverole in } \\
\text { assisting users with } \\
\text { technology." } \\
\text { Students have a } \\
\text { generally positive } \\
\text { impression of } \\
\text { librarians' attitudes } \\
\text { towards them but } \\
\text { aren't sure librarians } \\
\text { are as willing to } \\
\text { change services or to } \\
\text { help during "crunch } \\
\text { time" (pp.139-140). }\end{array}$ & $\begin{array}{l}\text { Students perceive } \\
\text { Information } \\
\text { Commons (IC) staff } \\
\text { as sources for } \\
\text { assistance, but not } \\
\text { academic assistance. } \\
\text { Students were } \\
\text { generally unaware of } \\
\text { educational } \\
\text { background of } \\
\text { academiclibrarians. } \\
\text { Students were unable } \\
\text { todistinguish between } \\
\text { types of IC staff. } \\
\text { Students viewed } \\
\text { staffattitudes and } \\
\text { skills positively. } \\
\text { Students had no } \\
\text { major problems with } \\
\text { the number and } \\
\text { location ofservice } \\
\text { desks (pp. 235-236). }\end{array}$ \\
\hline
\end{tabular}




\section{Methodology}

This study used an online survey to collect data from undergraduate students at James Madison University (JMU) $(N=19,665)$ in fall 2017. The IRB-approved instrument was adapted from earlier surveys by Hernon and Pastine (1977) and Fagan (2003) to collect both quantitative and qualitative data through a mix of closed and open-ended questions (See Appendix). The authors adapted the survey questions slightly for each of the three populations (librarians, undergraduates, and non-librarian faculty). Students who participated and provided their email address in a separate survey were eligible for a prize drawing (10 campus dining vouchers, each worth \$11).

The authors used Qualtrics survey software to create the survey; it remained open for five weeks. To support a balanced survey pool, liaison librarians at JMU identified 55 courses to target (from 100-level to 400-level in each college) and invited faculty teaching those courses to distribute the survey to students. Some faculty provided extra credit, tracked through a separate form. In addition to this pool, the survey also was distributed to all undergraduates via mass email. Quantitative data from the survey were analysed using SPSS versions 23 and 26. Qualitative data were coded using NVivo software version 12 using the same codebook as previous studies. Two authors independently coded all responses to open-ended questions, occasionally discussing new categories based on emerging themes. The authors jointly reviewed all references in a Not Coded Elsewhere (NCE) node for each question to ensure the response didn't fit into an existing category. The NVivo coding comparison showed $92 \%$ agreement on coded references. When the number of coded references diverged, the average between the two was rounded up to the next whole number and used as the final total for that category. 


\section{Results}

\section{Demographics}

While 513 responses were received, only 452 students persisted past the first section ("You and your experience with librarians") and completed at least 5 items on Q10. Therefore, these 452 were used as the final sample, for a response rate of $2.3 \%$. On Q22, more students dropped out; only 235 students answered at least 7 items on the set.

A series of chi-square goodness-of-fit tests was conducted on the proportion of respondents by gender, by major, and by year to determine how well the samples of 452 and 235 represented the JMU population. There were significant differences between the samples and the population. Notably, ${ }^{1}$ the sample was composed of:

- A higher proportion of women (19\% and $24 \%)$

- A higher proportion from the College of Health and Behavioral Studies (15\% and 26\%) and a lower proportion from the College of Integrated Science \& Engineering (-7\% and $5 \%)$

- A lower proportion of first-year students (-14\% and $-13 \%)$ and a higher proportion of seniors $(10 \%$ and $22 \%)$

- From the sample of 235, a lower proportion from the College of Business (-7\%).

Therefore, our samples do not statistically represent the JMU population, and overrepresent women, seniors, and students from the College of Health and Behavioral Studies; and

${ }^{1}(>=5 \%$ difference $)$

p. 6 
they underrepresent men, first-years, and students from the College of Integrated Science and

Engineering. On Q22, responses underrepresent students from the College of Business.

As the results are quite lengthy, a summary is provided in Table 2.

Table 2. Summary of findings: Student perceptions of librarians.

- Most students who consult with librarians credited librarians with contributing to their academic success.

- Many students valued librarians' expertise, interpersonal skills, and skills with resources, especially books.

- Compared to previous studies, this student sample was more aware of librarians' knowledge of how to use information, not just how to locate and access it.

- Students continued to underestimate librarians' education and salary, even though they (still) perceived librarians as faculty.

- Compared to previous studies, this student sample was more aware of the variety of librarian duties, including librarians' teaching work; however, some librarian activities remain hidden.

- Students found librarians helpful, respectful, and approachable.

- Most students don't ask for help in college because they don't see the need, despite doing so in grade school, middle school, and high school.

- Students' association between librarians and books remains strong, and students might not ask for help unless they need books.

\section{Library Consultation Experience \& Perceptions of Librarians Helping Students Succeed}

Students reported consulting librarians in a public library as children, with $58 \%{ }^{2}$ saying they consulted "Several times per year" or more (Figure 1). By the time they were in high school, however, a majority $(60 \%)$ reported consulting public librarians "Less than once per year" or "Never." A much higher proportion of students said they consulted with their school's librarians in grade school, with $81 \%$ saying they consulted "Several times per year" or more (Figure 2). Even in middle school and high school, a majority- $72 \%$ and $61 \%$, respectivelysaid they consulted with their school's librarian at least several times per year. Only $25 \%$ of

\footnotetext{
${ }^{2}$ Throughout the manuscript, percentage totals such as this may differ by up to up to $1 \%$ from
} calculations based on the figures due to rounding the percentages used in labels. 
students reported consulting with an academic librarian during college several times per year or more, and $43 \%$ said they "Never" consulted with an academic librarian.

Figure 1. How often have you consulted librarians in a public library? (Q4)

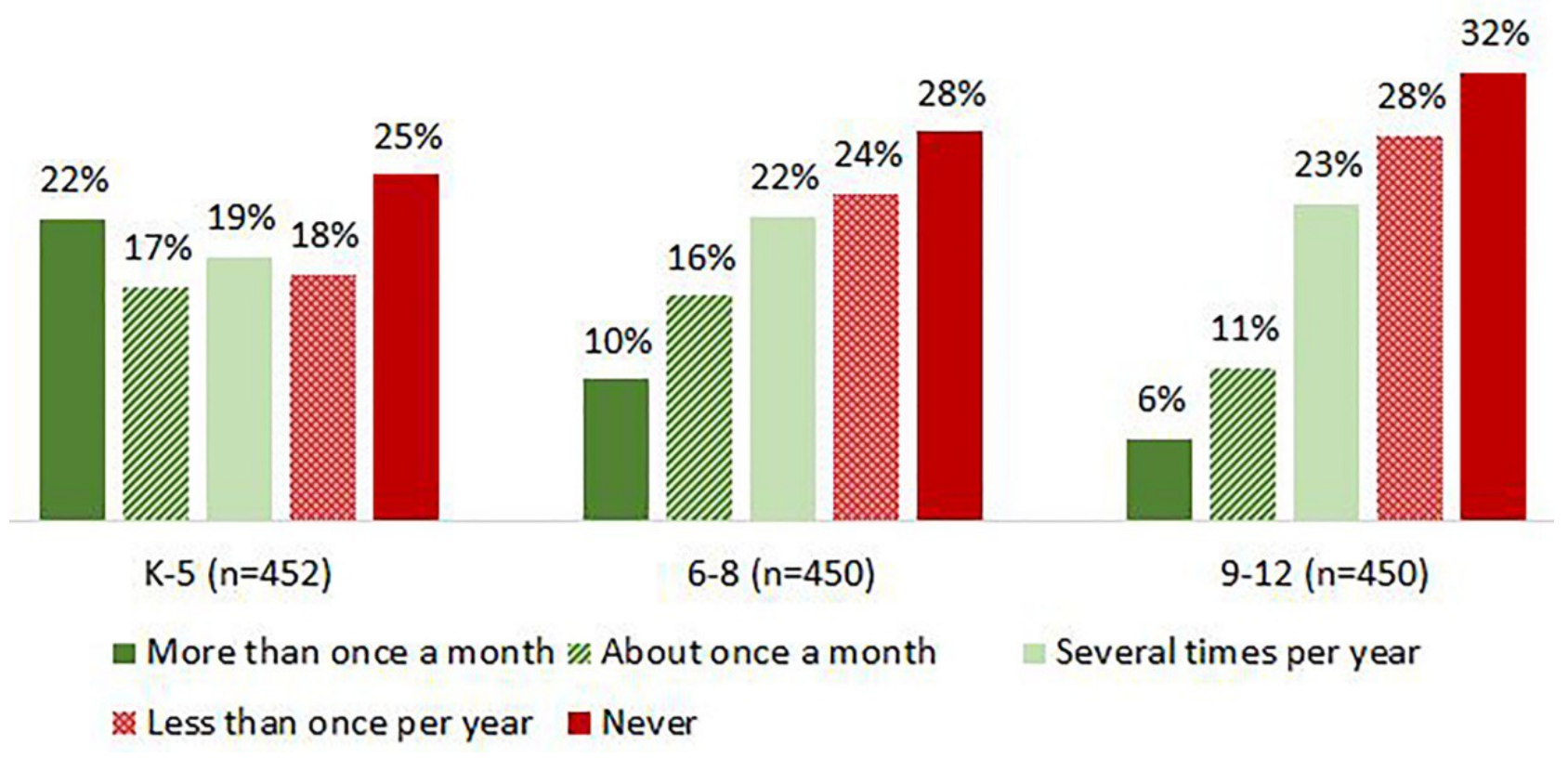

p. 8 
Figure 2. How often did you consult your school's librarian? (Q5) and How often have you consulted an academic librarian during your college years? (Q7).

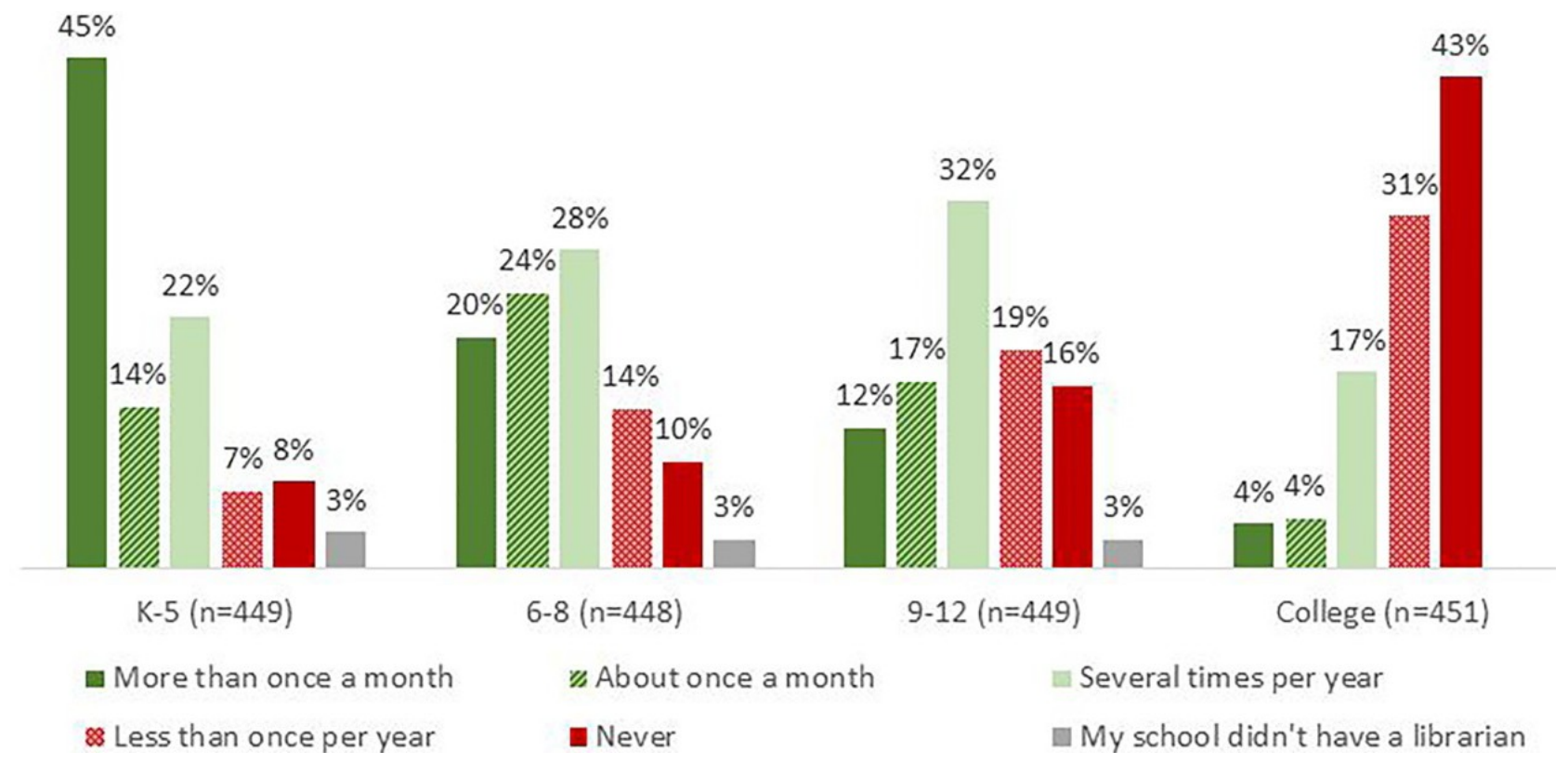

Note: "My school didn't have a librarian" was not an option for College.

Students reported that librarians helped them succeed more in their earlier school years, especially during grades K-5 (Q6, Figure 3). Fifty-three percent of students said librarians helped them succeed in college at least a little, 30\% said "None at all," and 16\% answered "Not Sure." 
Figure 3. To what extent, if any, do you think librarians helped you succeed? $(Q 6, Q 8)$.

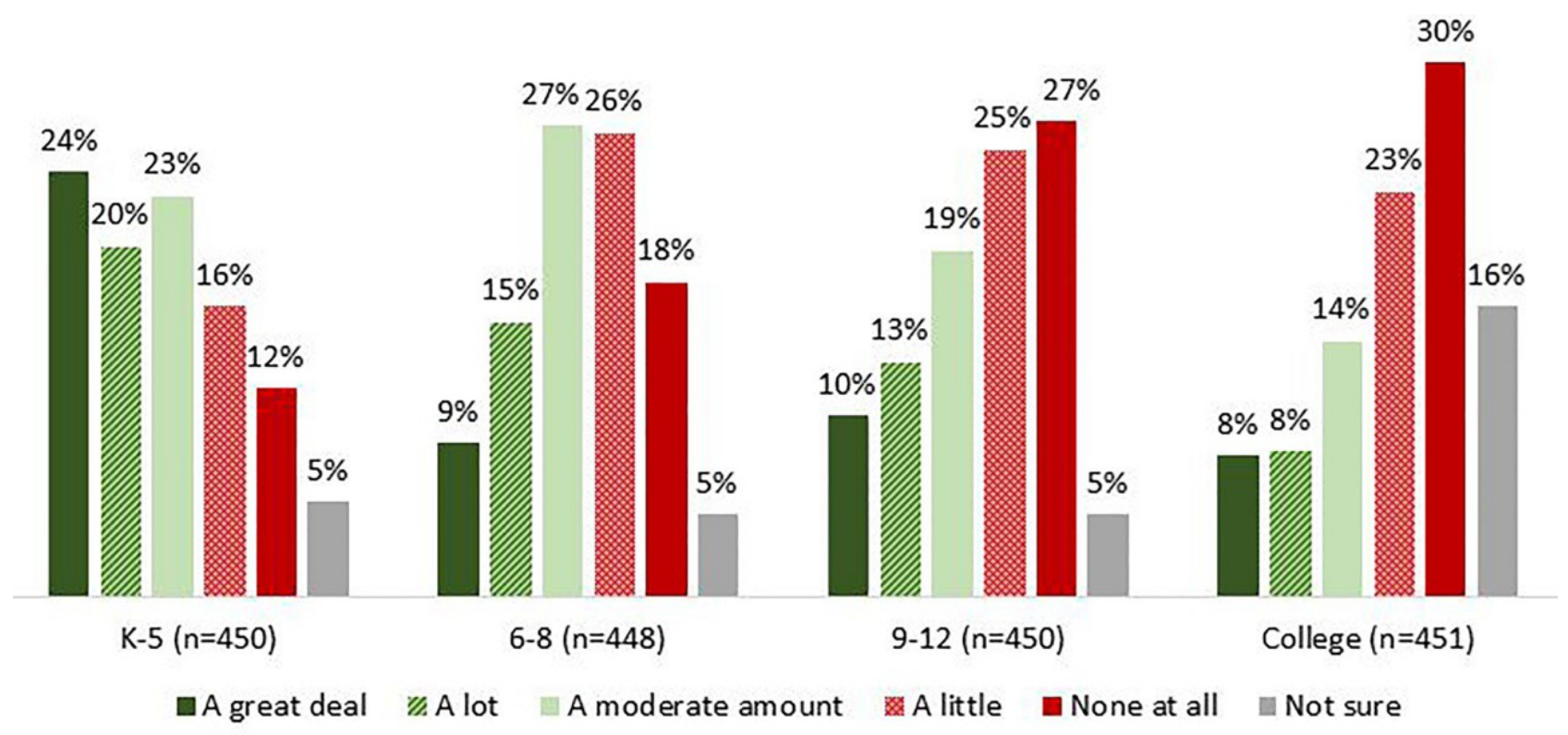

What Librarians Know: Librarian Expertise and skills /Value for librarians' skills

More than half our respondents (55\%) said a bachelor's degree was the minimum level of education required to be hired as an entry-level JMU librarian (Q20, $n=446)$. Fourteen percent chose "Master's degree," 14\% chose "High-school degree," and 14\% chose "Some college classes." In response to "How much do you think an entry-level JMU librarian makes per year?," the most frequent response was $\$ 30,000-\$ 39,999$ per year $(30 \%$ ), followed by $\$ 40,000-\$ 49,999$ per year (24\%), which is lower than both actual entry-level salaries and the faculty perception of salaries (Figure 4). 
Figure 4. Actual entry-level librarian salaries $(n=5)$ and perceptions of entry-level librarian salaries (Faculty Q10, $n=123$; Student Q15, $n=445$ ).

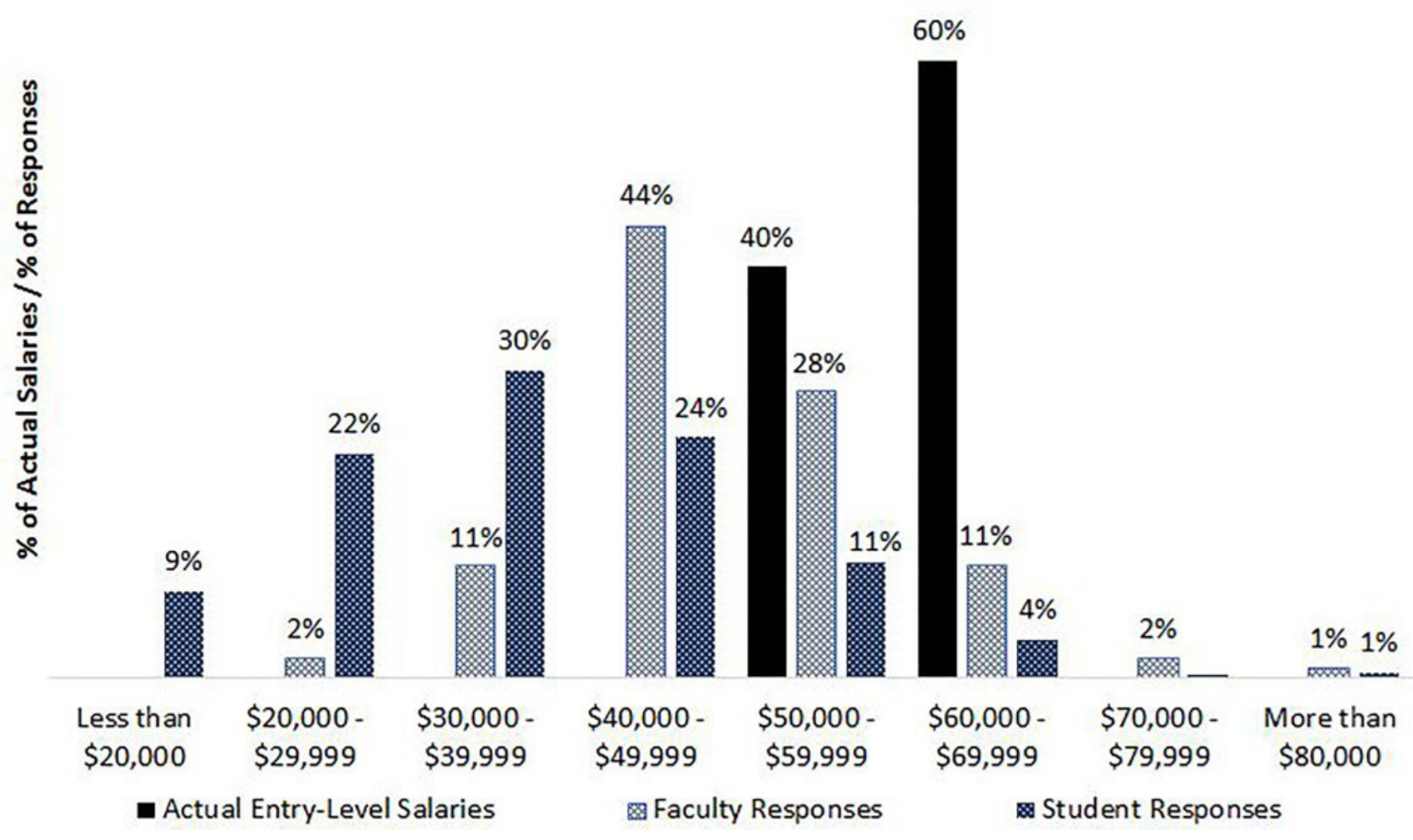

Three hundred thirty-two students $(73 \%)$ responded to the question "What do you think academic librarians learn in their library classes? Please write at least three topics you think are covered in library school classes" (Q21). Responses were coded with one or more categories, for a total of 1,166 coded references (or "mentions"). Definitions for these categories are shown in Table 3. Only categories that accounted for at least $3 \%$ of the total coded references are highlighted in Figure 5. 
Figure 5. What do you think academic librarians learn in their library classes? (Q21, Total Respondents $=332$; Total coded references $=1,166 ; \mathrm{NCE}=$ Not Coded Elsewhere).

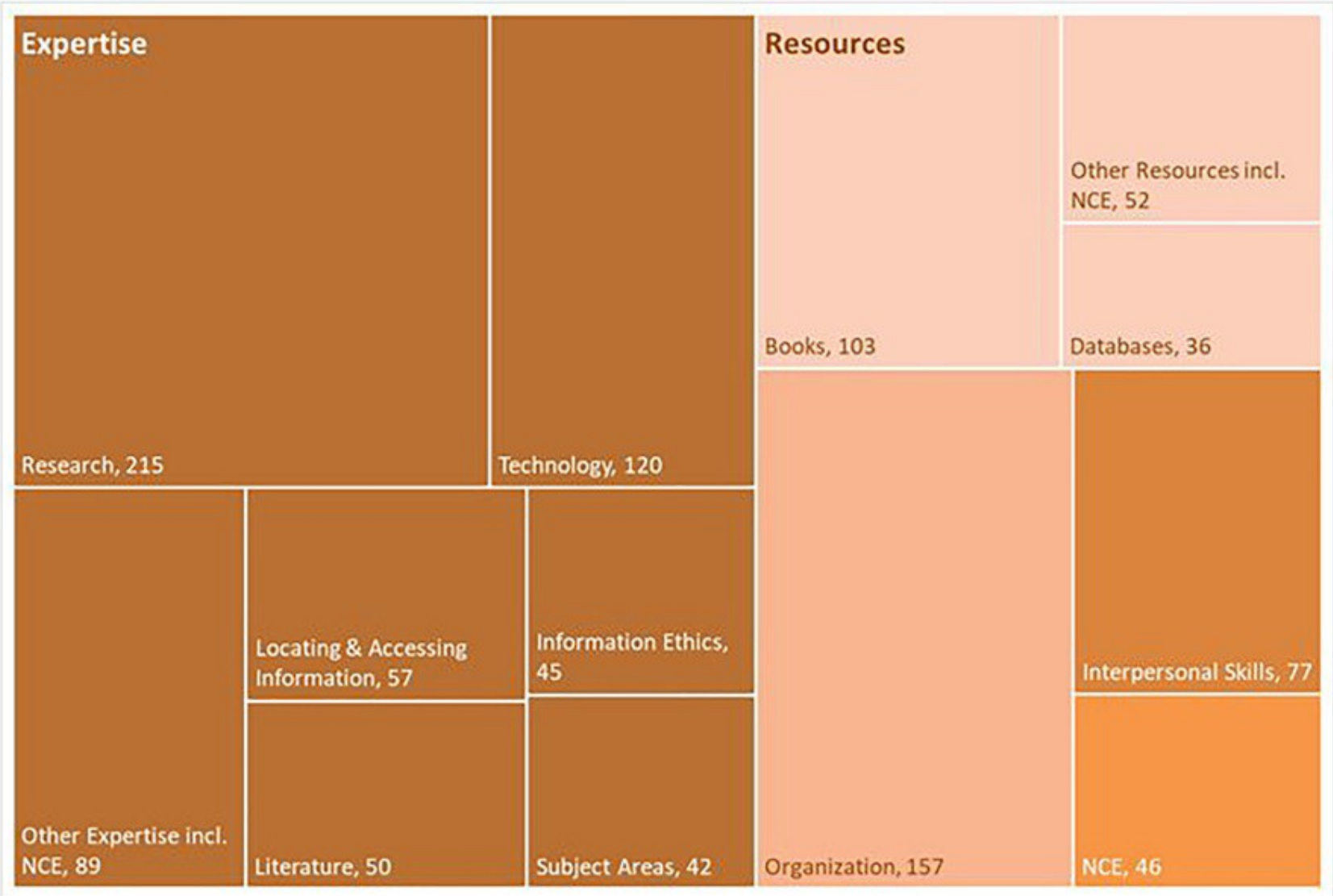

Table 3. Definitions for coding "What do you think academic librarians learn in their library classes?" and "What skills do you think librarians have..." 


\begin{tabular}{|c|c|c|c|c|}
\hline $\begin{array}{l}\text { Category / } \\
\text { Subcategory }\end{array}$ & Description & $\begin{array}{l}\text { Example responses in } \\
\text { Librarian survey } \\
\text { (Q5, Q6 \& Q9) }\end{array}$ & $\begin{array}{l}\text { Example responses in } \\
\text { Faculty Survey } \\
\text { (Q11, Q12 \& Q16) }\end{array}$ & $\begin{array}{l}\text { Example responses in } \\
\text { Student Survey }(\mathrm{Q} 16, \mathrm{Q} 17 \text { \& } \\
\text { Q21) }\end{array}$ \\
\hline $\begin{array}{l}\text { Data \& } \\
\text { Information } \\
\text { Management } \\
\end{array}$ & $\begin{array}{l}\text { Specific mentions of } \\
\text { managing data and/or } \\
\text { information }\end{array}$ & $\mathrm{N} / \mathrm{A}$ & $\begin{array}{l}\text { "Data management skills" } \\
\text { "Structures of information organization and } \\
\text { management" }\end{array}$ & "Information management" \\
\hline $\begin{array}{l}\text { Expertise / } \\
\text { Evaluating } \\
\text { Information }\end{array}$ & $\begin{array}{l}\text { An ability to determine the } \\
\text { quality of information or } \\
\text { sources }\end{array}$ & $\begin{array}{l}\text { "Discerning quality } \\
\text { information." }\end{array}$ & $\begin{array}{l}\text { "How to instruct faculty and students on } \\
\text { strategies for resource identification" } \\
\text { "They help provide and evaluate access of all } \\
\text { variety of information" }\end{array}$ & $\begin{array}{l}\text { "Can give information on the } \\
\text { best sources to use" } \\
\text { "How to know if something is } \\
\text { reliable" }\end{array}$ \\
\hline \begin{tabular}{|l|} 
Expertise / \\
General Library- \\
Related \\
Knowledge
\end{tabular} & Librarians "knowing stuff" & $\begin{array}{l}\text { "An understanding of how } \\
\text { information flows through } \\
\text { society:" }\end{array}$ & $\begin{array}{l}\text { "A broad general knowledge of current } \\
\text { resources, literature, and trends in all fields" } \\
\text { "Professional knowledge" }\end{array}$ & $\begin{array}{l}\text { "Library knowledge" } \\
\text { "Extensive knowledge" }\end{array}$ \\
\hline $\begin{array}{l}\text { Expertise / } \\
\text { Generating } \\
\text { Knowledge } \\
\end{array}$ & $\begin{array}{l}\text { Librarians producing their } \\
\text { own research and } \\
\text { scholarship }\end{array}$ & $\mathrm{N} / \mathrm{A}$ & $\begin{array}{l}\text { "Conducting their own research" } \\
\text { "Produce scholarship related to information } \\
\text { literacies" }\end{array}$ & "Doing research" \\
\hline $\begin{array}{l}\text { Expertise / } \\
\text { Information } \\
\text { Ethics }\end{array}$ & $\begin{array}{l}\text { Ethical use of information, } \\
\text { including copyright, author's } \\
\text { rights, citation, and } \\
\text { plagiarism }\end{array}$ & $\mathrm{N} / \mathrm{A}$ & $\begin{array}{l}\text { "Legal and ethical issues e.g. intellectual } \\
\text { property" } \\
\text { "Citing of research used" }\end{array}$ & $\begin{array}{l}\text { "How to properly cite" } \\
\text { "Keep the students from } \\
\text { plagiarizing" }\end{array}$ \\
\hline $\begin{array}{l}\text { Expertise / } \\
\text { Information } \\
\text { Literacy } \\
\end{array}$ & $\begin{array}{l}\text { Specific mentions } \\
\text { of "information literacy" }\end{array}$ & $\mathrm{N} / \mathrm{A}$ & $\begin{array}{l}\text { "Information literacy skills" } \\
\text { "Assisting university/faculty with research, } \\
\text { writing, and/or information literacy" }\end{array}$ & $\mathrm{N} / \mathrm{A}$ \\
\hline $\begin{array}{l}\text { Expertise / Library } \\
\text { \& Information } \\
\text { Science }\end{array}$ & $\begin{array}{l}\text { Library or } \\
\text { Information Science as } \\
\text { academic disciplines }\end{array}$ & $\mathrm{N} / \mathrm{A}$ & $\begin{array}{l}\text { "Library information history" } \\
\text { "Basic library science" }\end{array}$ & $\begin{array}{l}\text { "Library science" } \\
\text { "The history of the discipline" }\end{array}$ \\
\hline \begin{tabular}{|l|} 
Expertise / \\
Locating \& \\
Accessing \\
Information
\end{tabular} & $\begin{array}{l}\text { Furnishing or finding needed } \\
\text { information; usually also } \\
\text { coded with a particular type } \\
\text { of resource (databases, } \\
\text { books, articles, data, etc.) }\end{array}$ & $\begin{array}{l}\text { "Deciphering where to find } \\
\text { information" } \\
\text { "Knowledge about how to } \\
\text { navigate an overwhelming ocean } \\
\text { of information" }\end{array}$ & $\begin{array}{l}\text { "Using and making available electronic tools } \\
\text { (databases etc.)" } \\
\text { "How to manipulate a word search" }\end{array}$ & $\begin{array}{l}\text { "How to find books" } \\
\text { "They can help me find the } \\
\text { information I need" }\end{array}$ \\
\hline $\begin{array}{l}\text { Expertise / } \\
\text { Preservation \& } \\
\text { Archives } \\
\end{array}$ & $\begin{array}{l}\text { Preservation of information } \\
\text { and materials, including } \\
\text { archival practices }\end{array}$ & $\mathrm{N} / \mathrm{A}$ & $\begin{array}{l}\text { "Archive strategies and techniques" } \\
\text { "Methods of preserving information" }\end{array}$ & $\begin{array}{l}\text { "Preservation techniques" } \\
\text { "Book repair" }\end{array}$ \\
\hline $\begin{array}{l}\text { Expertise / } \\
\text { Research }\end{array}$ & $\begin{array}{l}\text { Research as either a noun, } \\
\text { adjective or a verb; usually } \\
\text { focused on processes }\end{array}$ & $\begin{array}{l}\text { "Ability to help students see } \\
\text { research as a process" }\end{array}$ & $\begin{array}{l}\text { "Research design and how to support } \\
\text { research" } \\
\text { "How to select and evaluate research resources } \\
\text { (journals, etc.)" }\end{array}$ & $\begin{array}{l}\text { "Research skills" } \\
\text { "How to do proper research" }\end{array}$ \\
\hline
\end{tabular}




\begin{tabular}{|c|c|c|c|c|}
\hline & & $\begin{array}{l}\text { "Thinking about different ways } \\
\text { to approach a research } \\
\text { problem" }\end{array}$ & & \\
\hline $\begin{array}{l}\text { Expertise / Subject } \\
\text { Areas }\end{array}$ & $\begin{array}{l}\text { References either knowledge } \\
\text { across many topics (General } \\
\text { Education expertise) or } \\
\text { subject specialties depending } \\
\text { on position }\end{array}$ & $\begin{array}{l}\text { "Subject expertise" } \\
\text { "Awareness of curriculum and } \\
\text { subject area" }\end{array}$ & $\begin{array}{l}\text { "Accessing subject-specific research and } \\
\text { putting it in a space where people from that } \\
\text { area can then use it" } \\
\text { "Knowledge of academic discipline (2nd } \\
\text { MA)" }\end{array}$ & $\begin{array}{l}\text { "Knowledge on different } \\
\text { subjects" } \\
\text { "Subject matter research } \\
\text { skills" }\end{array}$ \\
\hline $\begin{array}{l}\text { Expertise / } \\
\text { Technology }\end{array}$ & $\begin{array}{l}\text { Computers, software, or } \\
\text { technology management } \\
\text { skills }\end{array}$ & $\begin{array}{l}\text { "Creating accessible documents, } \\
\text { spreadsheets, and web } \\
\text { materials" } \\
\text { "Human-computer interaction" }\end{array}$ & $\begin{array}{l}\text { "Library-related technology" } \\
\text { "Instructional technology" }\end{array}$ & $\begin{array}{l}\text { "Can help students with } \\
\text { technology" } \\
\text { "Technology skills" }\end{array}$ \\
\hline \begin{tabular}{|l|} 
Expertise / \\
Writing \& Papers
\end{tabular} & $\begin{array}{l}\text { Writing, formatting research } \\
\text { papers }\end{array}$ & $\mathrm{N} / \mathrm{A}$ & $\begin{array}{l}\text { "Helping students to do proper research and } \\
\text { write proper research" } \\
\text { "How to write and cite research papers" }\end{array}$ & $\begin{array}{l}\text { "Writing research papers" } \\
\text { "Writing competency" }\end{array}$ \\
\hline $\begin{array}{l}\text { Higher-Order } \\
\text { Thinking }\end{array}$ & $\begin{array}{l}\text { Analytical or problem- } \\
\text { solving skills }\end{array}$ & $\begin{array}{l}\text { "Critical thinking", } \\
\text { "abstract thinking" }\end{array}$ & $\begin{array}{l}\text { "Ability to synthesize information" } \\
\text { "Creative problem solving" }\end{array}$ & $\begin{array}{l}\text { "Critical thinking skills" } \\
\text { "Problem solving" }\end{array}$ \\
\hline $\begin{array}{l}\text { Interpersonal } \\
\text { Skills }\end{array}$ & $\begin{array}{l}\text { Communication skills, } \\
\text { customer service skills, social } \\
\text { skills, or personal } \\
\text { qualities such } \\
\text { as "patient" or "intelligent" }\end{array}$ & $\begin{array}{l}\text { "Empathy" } \\
\text { "Curiosity" }\end{array}$ & $\begin{array}{l}\text { "Effective communication skills" } \\
\text { "Customer service type stuff" }\end{array}$ & $\begin{array}{l}\text { "People skills" } \\
\text { "They are helpful and kind" }\end{array}$ \\
\hline \begin{tabular}{|l|} 
Library Facilities / \\
Library as Place
\end{tabular} & $\begin{array}{l}\text { About the library as a } \\
\text { building, as a place }\end{array}$ & N/A & $\begin{array}{l}\text { "Maintaining the library" } \\
\text { "How to manage facilities" }\end{array}$ & $\begin{array}{l}\text { "Maintaining the library as an } \\
\text { area for people to get work } \\
\text { done" } \\
\text { "Knowledge of the facility" }\end{array}$ \\
\hline Organization & $\begin{array}{l}\text { Arranging items logically } \\
\text { (e.g., classification systems) } \\
\text { or the skills and knowledge } \\
\text { required to carry out these } \\
\text { tasks }\end{array}$ & "organizational skills" & $\begin{array}{l}\text { "Classifying and cataloguing information" } \\
\text { "Structures of information organization and } \\
\text { management" }\end{array}$ & $\begin{array}{l}\text { "Organization of books" } \\
\text { "Dewey decimal system" }\end{array}$ \\
\hline \begin{tabular}{|l|} 
Reference \\
Skills \& Reference \\
Interview
\end{tabular} & $\begin{array}{l}\text { Specific mentions } \\
\text { of "reference" in the context } \\
\text { of helping users identify what } \\
\text { they need }\end{array}$ & $\begin{array}{l}\text { "The 'reference interview' and } \\
\text { how people don't always know } \\
\text { how to ask for what they need." } \\
\text { "Reference skills" }\end{array}$ & $\begin{array}{l}\text { "Reference" } \\
\text { "Information trends (how people access } \\
\text { information and what information they } \\
\text { want)" }\end{array}$ & "Basic reference classes" \\
\hline
\end{tabular}


Students indicated that Library and Information Science (LIS) programs developed librarians' Expertise, accounting for 53\% of all coded references (618 mentions). The largest sub-category was Research (215 mentions), followed by Technology (120), Locating \& Accessing Information (57), Literature (50), Information Ethics (45), Subject Areas (42), and Other Expertise, including NCE responses (89). Examples of other types of expertise included:

Writing \& Papers, Evaluating Information, Preservation \& Archives, and General LibraryRelated Knowledge.

Some students characterised librarians' knowledge and abilities as "proper," "right," or "correct." There were 18 mentions using the word "proper," 11 of these with the word "research" (e.g., "how to do proper research"). Other activities properly done by librarians included "proper book searching," "proper use of technology," and "how to properly cite in a paper." Responses suggested that librarians learn the more traditional skills of finding needed information, usually coded with a particular type of resource (database, books, articles, etc.), and that librarians develop "extensive knowledge"-they just know stuff.

Sixteen percent of coded references to this question indicated that LIS curriculums include courses related to Resources (191 mentions), whether materials generically (holdings, resources, stuff, etc.) or specifically (articles, books, data, databases, etc.). Comments recognised that librarians acquire "book knowledge" and "knowledge of scholarly resources." There were 103 mentions of books, accounting for more than half of the coded references to Resources.

Statements about Organization or the skills and knowledge required to carry out such tasks garnered 157 mentions. Interpersonal Skills accounted for 7\% (77) of mentions. Only 4\% 
of mentions referred to administrative tasks like bookkeeping, filing, learning Microsoft, publishing, and analysing program effectiveness (all coded in the NCE category). Categories that failed to meet the $3 \%$ threshold included Teaching \& Pedagogy (10 mentions), Higher-Order Thinking (13), and Unspecified Help (1). Data \& Information Management, a category that emerged in the faculty results, was mentioned just once.

In contrast to the dominance of responses directly related to library work, only two respondents drew on pop-culture librarian stereotypes, suggesting our coursework included "shhhhh-ing skills" and "5 best hair bun techniques."

Three hundred and forty-one students (75\%) responded to the question "What skills do you think librarians have that are valuable to you?" (Q16) for a total of 754 coded references. As before, only categories included in at least $3 \%$ of the total coded references are highlighted in Figure 6. Again, Expertise stood out (387 mentions), followed by Resources (144), Interpersonal Skills (109), and Organization (45). Library as Place and NCE mentions barely met the 3\% threshold. Definitions for these categories were the same as for the library school question (Q21) (see Table 3).

p. 16 
Figure 6. What skills do you think librarians have that are valuable to you? (Q16, Total Respondents $=341$; Total coded references $=770$; $\mathrm{NCE}=$ Not Coded Elsewhere; DBs=databases).

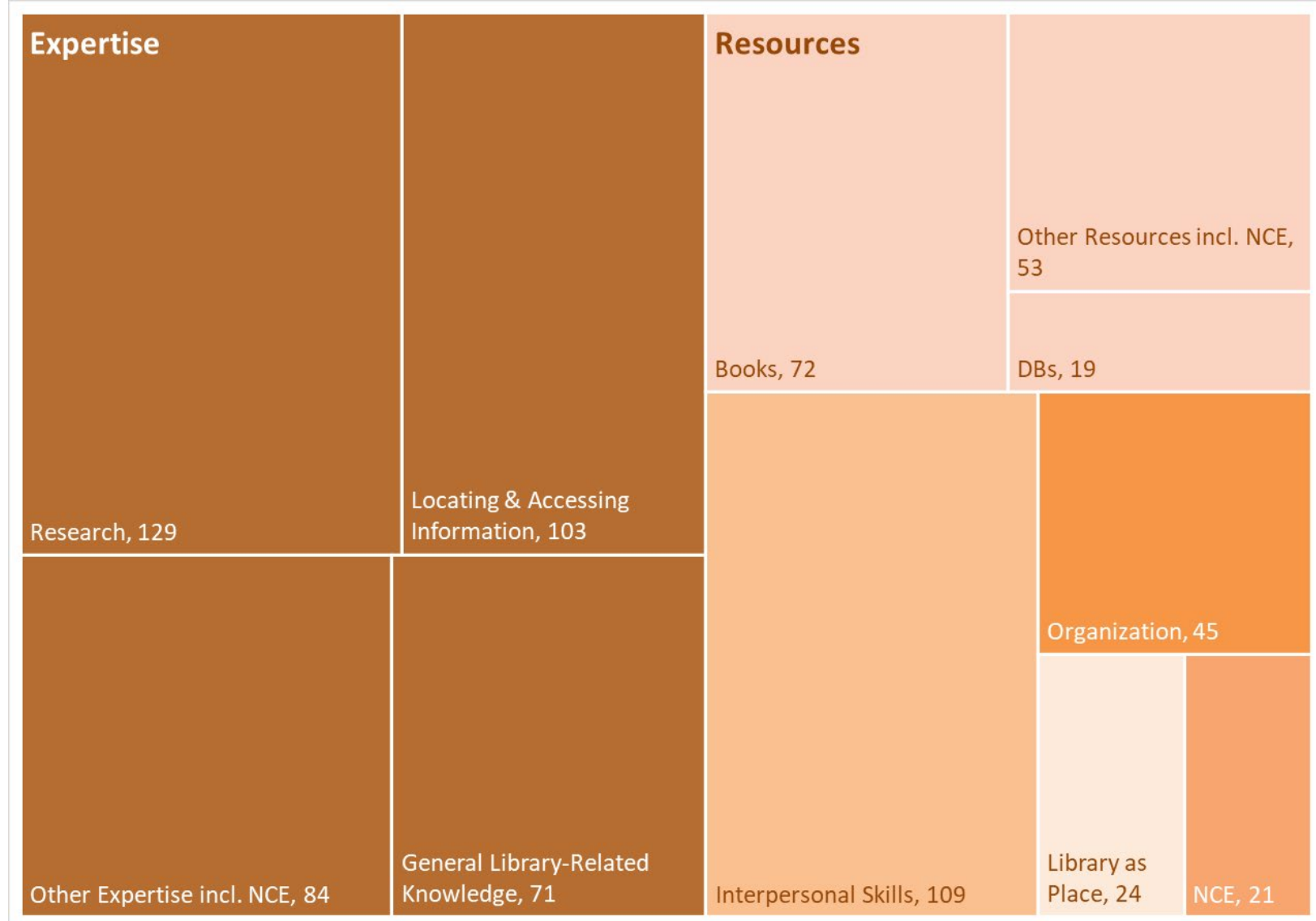

Within the most frequently cited category, Expertise, student responses emphasized librarians' Research skills (129 mentions) and skills Locating \& Accessing Information (103). Eleven percent of mentions were categorized as Other Expertise, including NCE statements like "the ability to receive little information and still come to a conclusion about various things" and "knowledge that any liberal arts professor or graduate would have." Less than $10 \%$ of mentions underscored librarians' General Library-Related Knowledge ('knowing stuff”) as useful to students. 
In the next most frequently mentioned category, Resources, only two specific types of resources met the 3\% threshold: Books (72 mentions) and Databases (19). Generic mentions of resources or library collections (e.g., "Resources") were collapsed with NCE in this category. Interpersonal Skills (e.g., "They are helpful and kind"), and the ability to organize (e.g., "Dewey decimal system"), garnered $14 \%$ and $8 \%$ of mentions, respectively. Library as Place and the NCE category received 3\% of mentions. Examples of comments in NCE included "a good eye for things," "high memory capacity," and "passionate about education."

Three hundred and twenty-nine students (73\%) responded to the question "What skills do you think librarians have that are valuable to the university?" (Q17) for a total of 625 coded references (see Figure 7). Reasons given were coded with the broad categories of Expertise (289 mentions), Resources (99), Interpersonal Skills (79), Organization (55), NCE (39), Unspecified Help (24) and Teaching \& Pedagogy (21). Definitions for these categories are shown in Table 3.

Figure 7. What skills do you think librarians have that are valuable to the university? (Q17, Total Respondents=329; Total coded references $=620$; NCE $=$ Not Coded Elsewhere). 


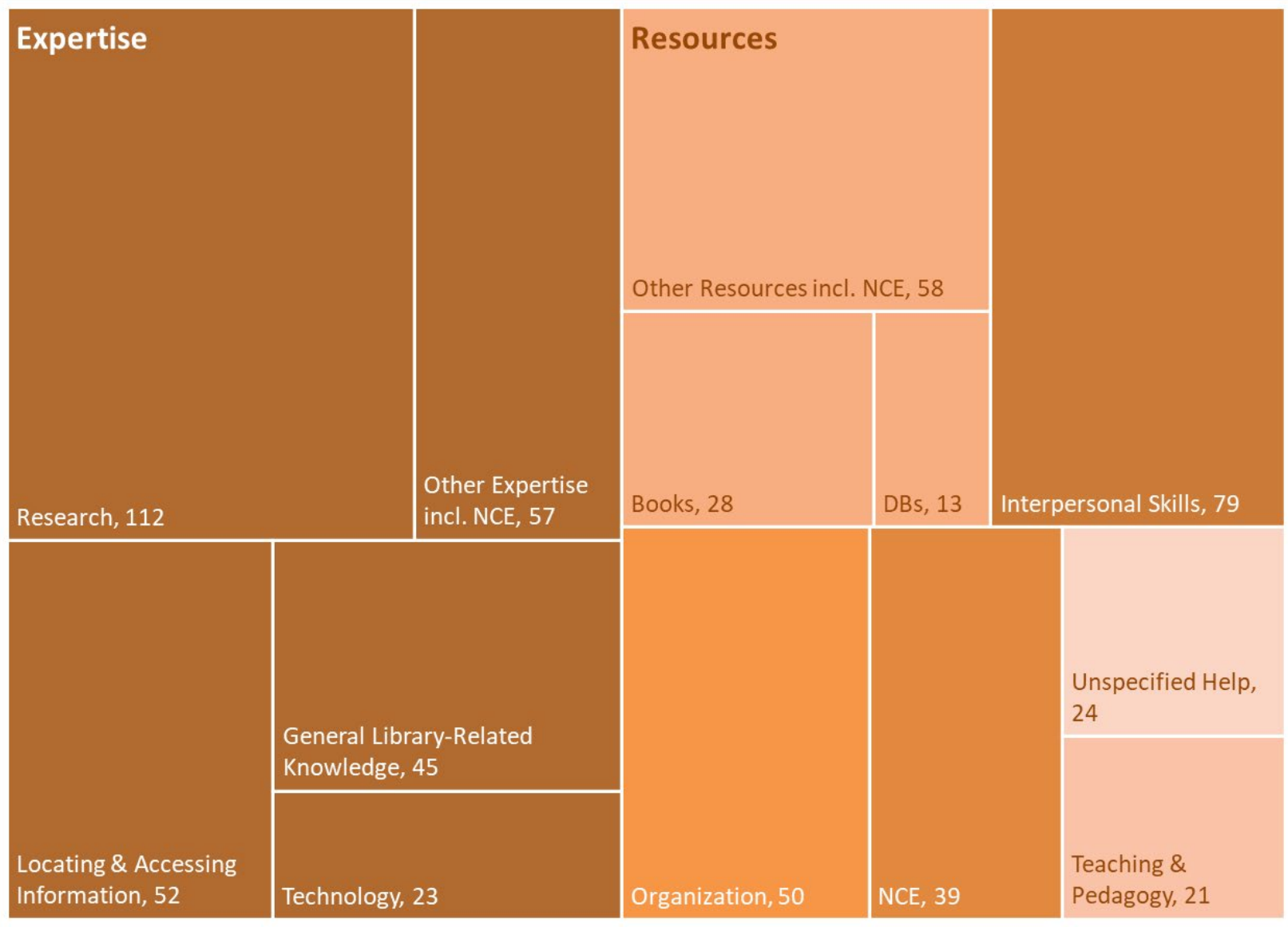

Students most frequently cited Expertise as the skill most valuable to the university, and Research (112 mentions) was the foremost sub-category. Students mentioned their value for librarians' awareness of needed books and their familiarity with different databases. Locating \& Accessing Information, General Library-Related Knowledge, and Other Expertise, including NCE, were listed in approximately $8 \%$ of mentions. Again, comments emphasized books, but acknowledged "understanding of information" as valuable. Students also recognised librarians' familiarity with copyright laws and "keeping our information safe and useful" as beneficial. Technology skills rounded out this category with 23 mentions. 
Resources was the next most frequent coded category, with 28 mentions of books and 13 mentions of databases. Other Resources, including NCE, accounted for 58 mentions (generic resources, articles and journals, and collections work).

Finally, for this question, students recognized librarians' Interpersonal Skills, (e.g., "People skills") (13\% of mentions), Organization (9\%), and NCE and other categories (6\%). Unspecified Help and Teaching \& Pedagogy complete the list.

Table 4 compares these results with previous studies; the question "Skills Valuable to University" is omitted since it was not asked in the other studies. 
Table 4. What librarians know: Comparison with previous studies.

\begin{tabular}{|c|c|c|c|c|}
\hline & $\begin{array}{l}\text { Hernon } \\
\text { \& Pastine (1977) }\end{array}$ & Fagan (2003) & \begin{tabular}{|l} 
Bickley \& \\
Corall (2011)
\end{tabular} & $\begin{array}{l}\text { Fagan, et al. } \\
(2021)\end{array}$ \\
\hline Degrees & $\begin{array}{l}8 \% \text { master's in library } \\
\text { science } \\
\text { Librarians differ from } \\
\text { student assistants and } \\
\text { clerical help ( } 87 \% \text { yes; } 5 \% \\
\text { no; } 8 \% \text { unsure) (p. 133) }\end{array}$ & \begin{tabular}{|l}
$15 \%$ master's \\
$57 \%$ bachelor's \\
$29 \%$ high school (p. 135)
\end{tabular} & \begin{tabular}{|l|}
$15 \%$ master's in \\
librarianship \\
$21 \%$ \\
undergraduate \\
$19 \%$ A-levels or \\
equivalent (p. 235)
\end{tabular} & \begin{tabular}{|l}
$14 \%$ master's \\
$56 \%$ bachelor's \\
$14 \%$ some college \\
$14 \%$ high school \\
$(<1 \%$ doctoral or \\
multiple graduate \\
degrees)
\end{tabular} \\
\hline Salary & $\mathrm{NA}$ & $\begin{array}{l}79 \% \text { chose one of the first four } \\
\text { ranges, indicating } \$ 25,000 \text { or less } \\
\text { per year (p. 137) }\end{array}$ & NA & $\begin{array}{l}\text { Respondents reported } \\
\text { lower than actual } \\
\text { entry-level salaries }\end{array}$ \\
\hline \begin{tabular}{|l|} 
Library \\
School \\
Topics \\
Learned
\end{tabular} & NA & 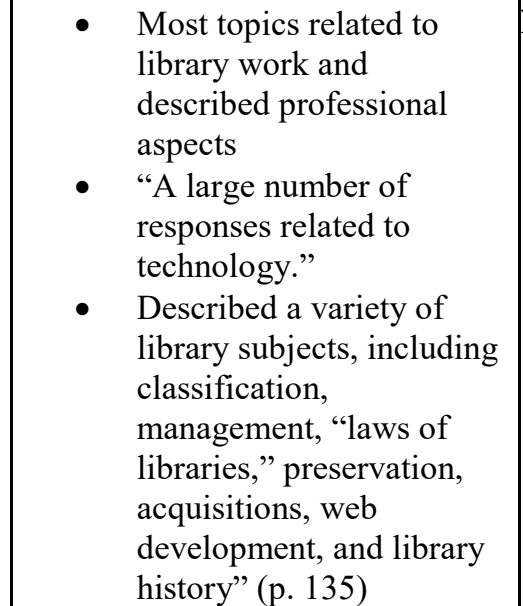 & NA & $\begin{aligned} & \text { Top Categories: } \\
&- \text { Expertise } \\
&- \text { Locating \& } \\
& \text { Accessing } \\
& \text { Information } \\
&- \text { General } \\
& \text { Library } \\
& \text { Knowledge } \\
&- \text { Collection } \\
& \text { Management }\end{aligned}$ \\
\hline & $\begin{array}{l}\text { "Students emphasised the } \\
\text { value of librarians' skills in } \\
\text { finding materials rather } \\
\text { than in how to use } \\
\text { materials: 'leading one to } \\
\text { knowledge rather than } \\
\text { imparting it"” (p. 132) }\end{array}$ & $\begin{array}{l}\text { - } \begin{array}{l}\text { Knowledge, particularly of } \\
\text { where resources are }\end{array} \\
\text { located and of computers } \\
\text { and the Internet } \\
\text { - Finding } \\
\text { materials emphasized more } \\
\text { than how to use materials } \\
\text { - } \text { "Significant number listed } \\
\text { character qualities" } \\
\text { - communication skills, } \\
\text { organizational skills, and } \\
\text { skills with the Internet and } \\
\text { computers" (p. 136) }\end{array}$ & NA & \begin{tabular}{|ll} 
Top Categories: \\
- & Expertise \\
- & Resources \\
- & Interpersonal \\
& Skills \\
- & Organization
\end{tabular} \\
\hline
\end{tabular}

\section{What Librarians Do: Duties of librarians}

As a group, more students thought they could tell which JMU Libraries' workers were librarians (46\%) than couldn't (29\%); this was not dissimilar to the faculty response, although more faculty answered Not Sure (31\%) than did students (23\%) (Q11, see Figure 8). Only 29\% 
of students ever asked to speak to a librarian, far fewer than faculty (63\%) (Q12). Similar to JMU faculty, a large majority of students (85\%) thought librarians were faculty at JMU, (Q13). A majority of respondents said "Yes" that librarians were faculty at every university $(62 \%, \mathrm{Q} 14)$, which was much higher than the faculty response $(22 \%)$.

Figure 8. Faculty and student perceptions of librarian characteristics (Faculty Q7 $n=122, Q 6, Q 8$, Q9 n= 126; Student Q11, Q12, Q13, Q14, n= 452).

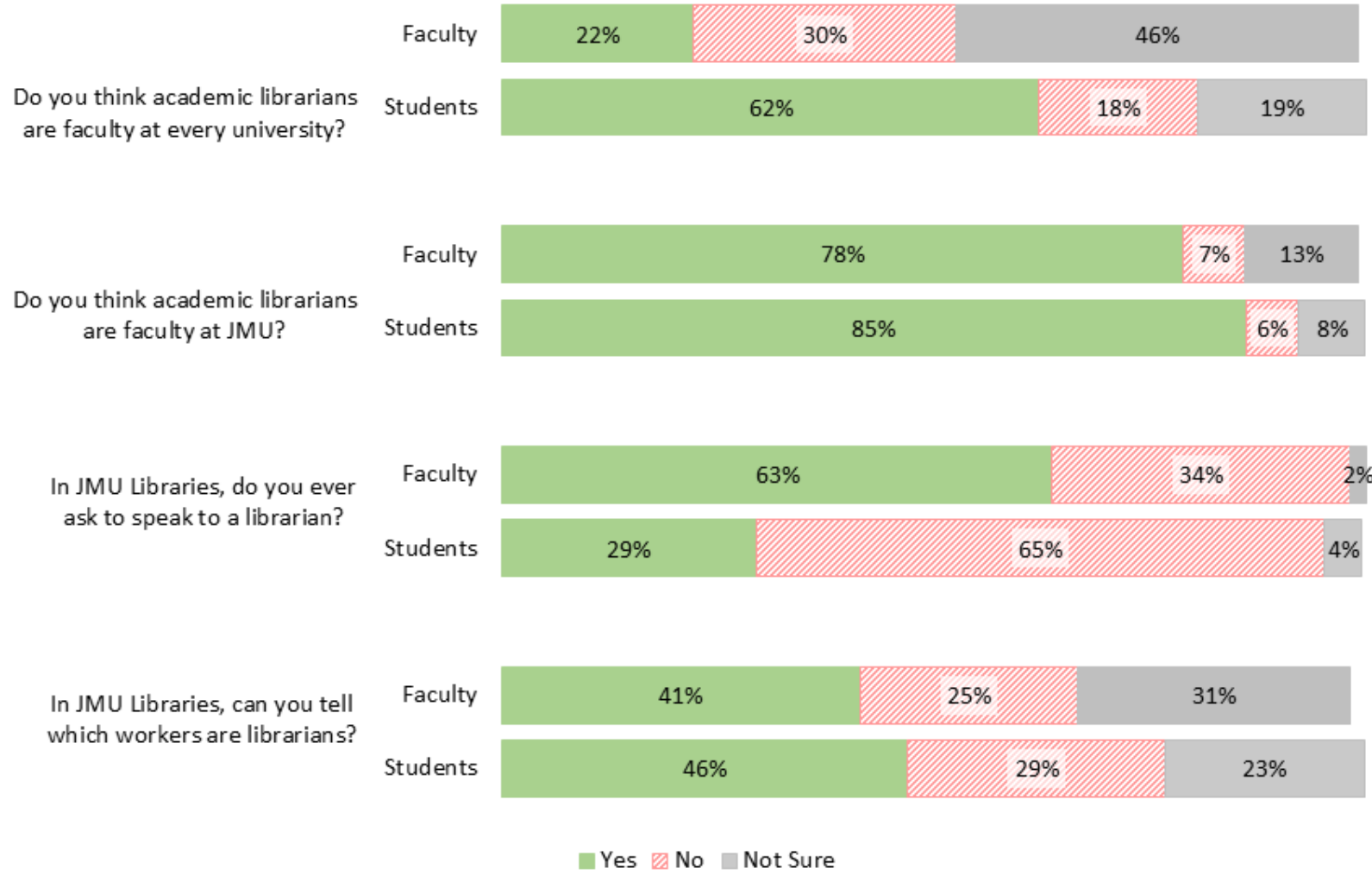

Note: Missing responses (not shown in chart) were $2 \%$ or less for each question for both groups.

On the set of questions asking, "How often do you think academic librarians perform the following duties" (Q10), there was 1 missing response for 7 items, 2 missing responses for 3 items, and 4 missing responses for 1 item. Eight items had more than 20 "Not Sure" responses: Creating subject guides (43), Working in Starbucks (34), Issuing library cards (31), Publishing 
research about the library profession (29), Evaluating student learning (25), Teaching software skills (in classes or one-on-one) (24), Creating online tutorials (21), and Planning special events at the library (21). "Not Sure" responses were changed to missing for subsequent analyses. A majority of respondents indicated that librarians Frequently engaged in 7 of the 26 listed duties: Giving general directional help (75\%), Lending books, films, and equipment to users (71\%), Helping users to find books (70\%), Giving general help to students for research (66\%), Sorting and putting books back on the shelves (60\%), Giving general help to faculty for research (57\%), and Giving subject-specific help to students for research (56\%) (Figure 9).

Figure 9. How often do you think academic librarians perform the following duties? (Q10).

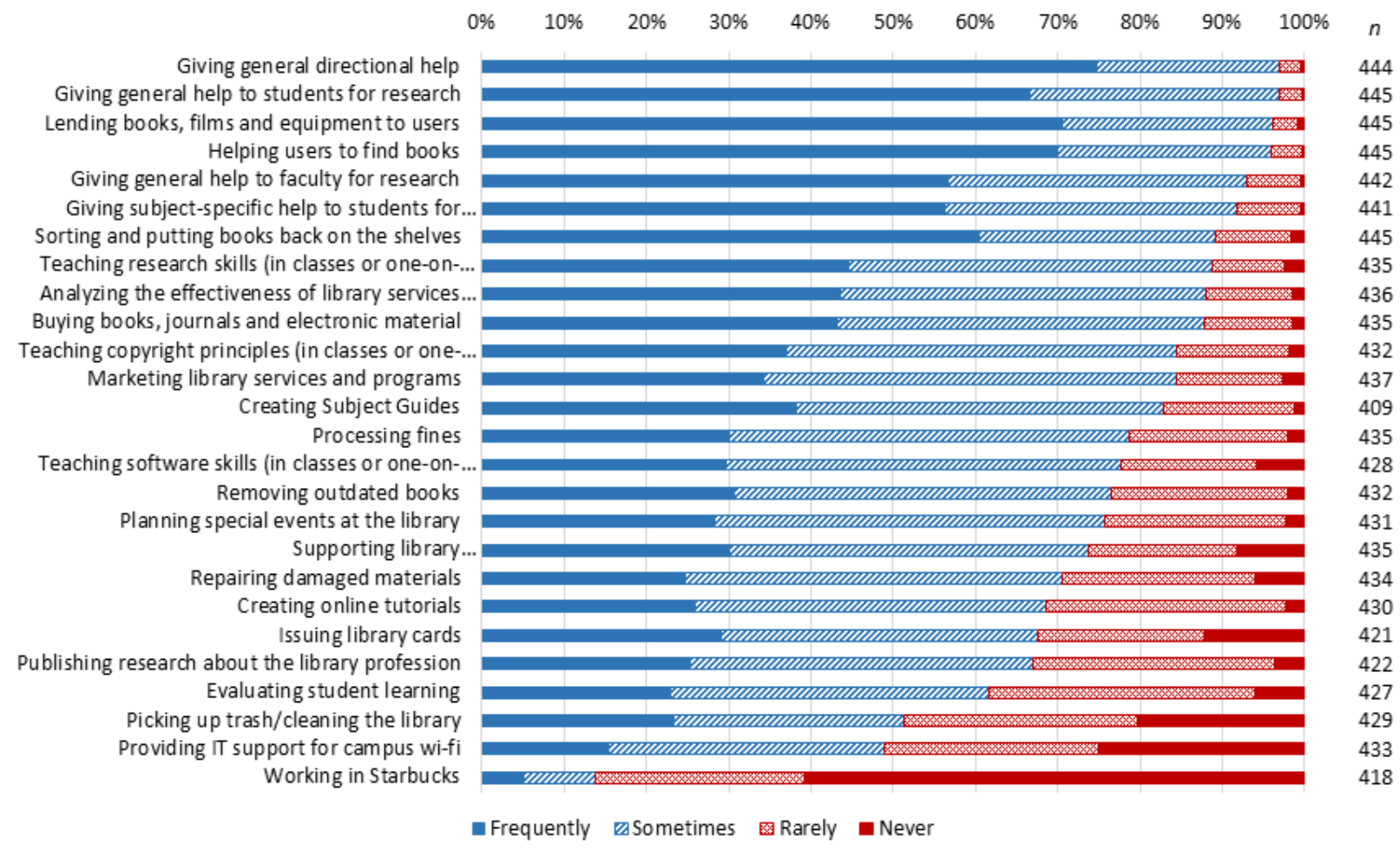

Note: See Appendix for full statements. Not Sure was also a response option; it was treated as missing data, not shown on chart. Sorted by total positive responses descending, then total negative responses ascending. 
Figure 10 shows the largest gaps between perceptions of librarians and students concerning librarian duties (difference $>=20 \%$ ), as well as the faculty responses to these items. Few librarians, but a substantial majority of students (68\% or more), believe librarians Support library computers/printers/photocopiers, Issue library cards, Repair damaged materials, Process fines, Lend books, films, and equipment to users, and Sort and put books back on the shelves. More than $89 \%$ of students believe librarians shelve and lend books. Students also believe librarians Provide IT support for campus wi-fi, Pick up trash, and Give general directional help more than librarians say they do these things. Faculty responses to these questions were much closer to librarians', except for repairing materials and lending books, where they were somewhere between student and librarian responses. Students also thought librarians did some things less than librarians do: Publishing research, Evaluating student learning, Creating online tutorials, and Removing outdated books. For Publishing research and Creating online tutorials, faculty were closer to librarians, but for Evaluating student learning and Removing outdated books, faculty were closer to students. 
Figure 10. Differences between librarian, faculty, and student perceptions of librarian duties (Librarian Q4, n= 19-20; Faculty Q5, $n=114-124$; Student Q10, $n=421-445$ ).

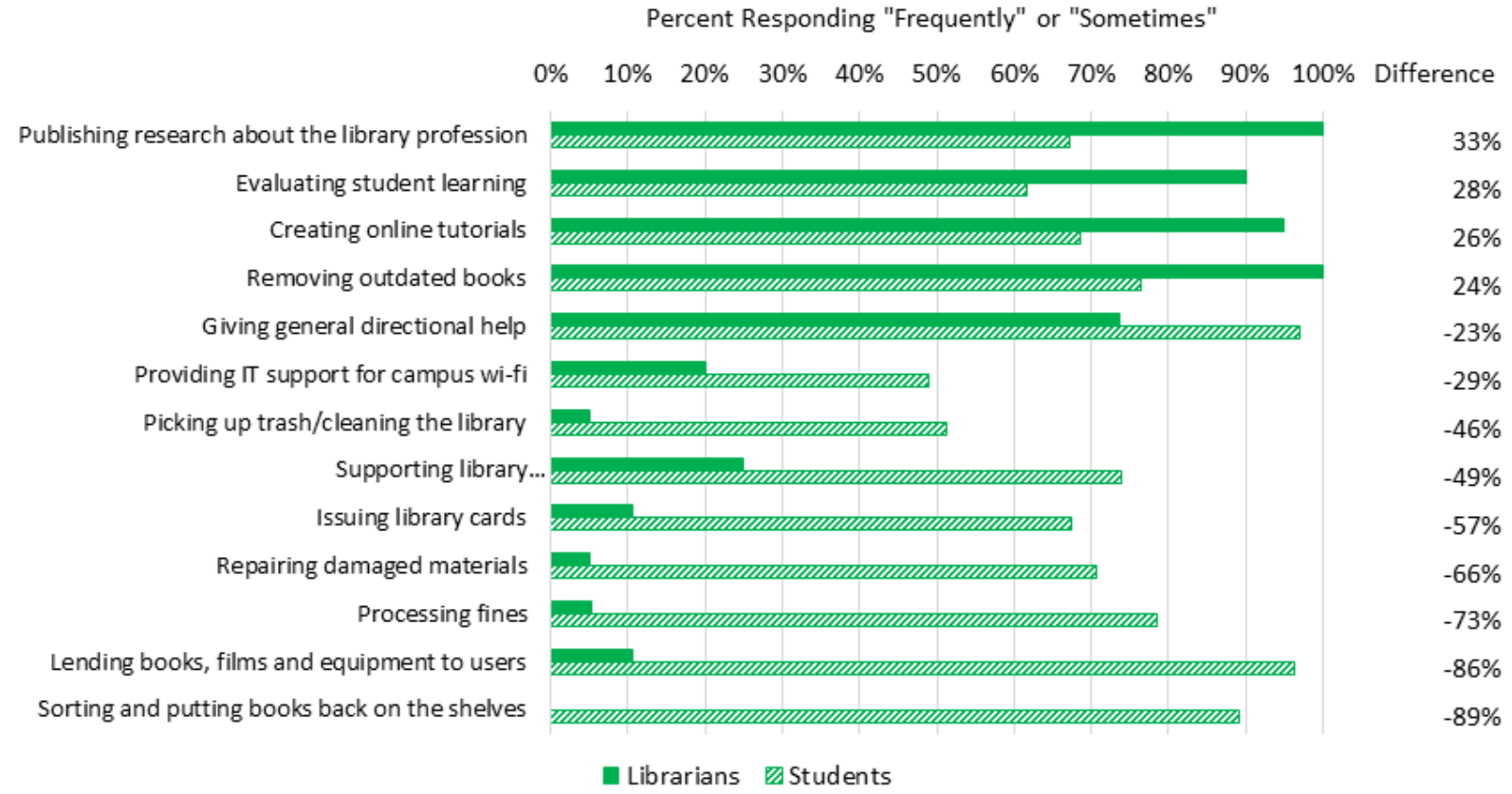

Relationships among the items comprising Q10, "How often do you think academic librarians perform the following duties?, were explored using similar methods to the prior studies (Fagan, et al., 2020a,) and students' clusters roughly corresponded to those for the librarian and faculty samples. Table 5 compares this section's results with previous studies. 
Table 5. What librarians do: Comparison with previous studies.

\begin{tabular}{|c|c|c|c|c|}
\hline & Hernon \& Pastine (1977) & Fagan (2003) & Bickley \& Corall (2011) & Fagan, et al. (2021) \\
\hline $\begin{array}{l}\text { Can you tell which } \\
\text { workers are } \\
\text { librarians? }\end{array}$ & $\begin{array}{l}50 \% \text { “did not know" (p. } \\
133)\end{array}$ & $\begin{array}{l}\text { "About half" of the } \\
\text { respondents said they } \\
\text { could" (p. 137) }\end{array}$ & Don't know: $67 \%$ p. 232 ) & $\begin{array}{ll}\text { - } & \text { Yes: } 47 \% \\
\text { - } & \text { No: } 29 \% \\
\text { - } & \text { Not Sure: } 23 \% \\
\end{array}$ \\
\hline $\begin{array}{l}\text { Do you ask to speak to } \\
\text { a librarian? }\end{array}$ & $\begin{array}{l}\text { - "Frequently" or “ } \\
\text { always" seek } \\
\text { assistance": } 16 \% \\
\text { (p. 134) } \\
\text { Ask "for a } \\
\text { professional } \\
\text { librarian": } \\
11 \% \text { (p. 133) } \\
\end{array}$ & - $\quad$ Yes: $8 \%$ & $\begin{array}{l}\text { "Sought assistance } \\
\text { from staff": } 62 \% \\
\text { - "Requested academic } \\
\text { assistance": } \\
2 \% \text { (p. 231) }\end{array}$ & - $\quad$ Yes: $29 \%$ \\
\hline $\begin{array}{l}\text { Are librarians faculty } \\
\text { at this institution? }\end{array}$ & NA & Yes: $85 \%$ & NA & Yes: $85 \%$ \\
\hline Duties of librarians & $\begin{array}{l}\text { "Generally } \\
\text { defined in terms } \\
\text { of a reference } \\
\text { function" (p. 132) } \\
\text { "Only 13 (4\%) } \\
\text { suggested a cataloging } \\
\text { and organizational } \\
\text { function and ten (3\%) an } \\
\text { acquisitions role" (p. } \\
132 \text { )- "Students } \\
\text { emphasized [reference } \\
\text { librarians'] role in } \\
\text { locating needed } \\
\text { information. 5\% indicated } \\
\text { collection building, but } \\
\text { none suggested } \\
\text { participation } \\
\text { in instructional outreach } \\
\text { programs" (p. 133)- }\end{array}$ & $\begin{array}{l}\text { "Reference } \\
\text { duties were most } \\
\text { frequently mentioned } \\
\text { followed by } \\
\text { circulation-related } \\
\text { activities, which were } \\
\text { clearly seen as } \\
\text { technical (e.g., "checks } \\
\text { out books"), and } \\
\text { cataloging/ organizatio } \\
\text { nal tasks, which were } \\
\text { vague (e.g., "organize } \\
\text { material"). } \\
\text { "Disturbing" r } \\
\text { esponses } \\
\text { included "plays } \\
\text { computer games," "sits } \\
\text { around," and "cleans" } \\
\text { (p. 137) }\end{array}$ & \begin{tabular}{|l} 
Top "Frequently" Answers: \\
the shelves \\
Putting books back on \\
students have reserved \\
Fooks \\
Helping students find \\
directional help \\
Giving general \\
journals, and electronic \\
material \\
Luying books, \\
computers/printers/ \\
copiers (p. 234)
\end{tabular} & $\begin{array}{l}\text { Top "Frequently" } \\
\text { Answers: } \\
\text { directional help } \\
\text { fingeneral } \\
\text { films and equipment to } \\
\text { users } \\
\text { find books } \\
\text { Helping users to } \\
\text { help to students for } \\
\text { research } \\
\text { putting books back on the } \\
\text { shelves } \\
\text { G Giving general } \\
\text { help to faculty for research } \\
\text { - Giving subject- } \\
\text { specific help to students for } \\
\text { research }\end{array}$ \\
\hline
\end{tabular}

\section{What Librarians Are Like: Motivations and affective behaviours}

Students were asked to rank from 1-10 a list of reasons librarians chose to become

librarians, with 1 as the top reason (Q9). There were 12 missing responses to this item. Figure 11

shows the aggregate responses sorted by mean. Like librarians, students chose "they want to help

people" as the top rank. But students ranked "they like books" as \#2, higher than faculty (\#6) and 
librarians (\#6). Students ranked "they like working with information" lower (\#6) than faculty (\#1) or librarians (\#2). Student responses, with their average $s d$ of 1.81 (not including “other”), were more variable than those of faculty $(s d=1.63)$ or librarians $(s d=1.39)$. Five students wrote in reasons for Other": "corresponds with their area of study," "happiness," "they always have a positive attitude on reading," "They are passionate about it," and "they like working with kids and building a foundation for them."

Figure 11. Perceptions of reasons librarians became librarians, sorted by student rank (Average rank on a scale of 1-10, with standard deviation error bars) (Librarian Q3, $n=20$; Faculty Q4, n= 126; Student Q9, $n=440$ ).

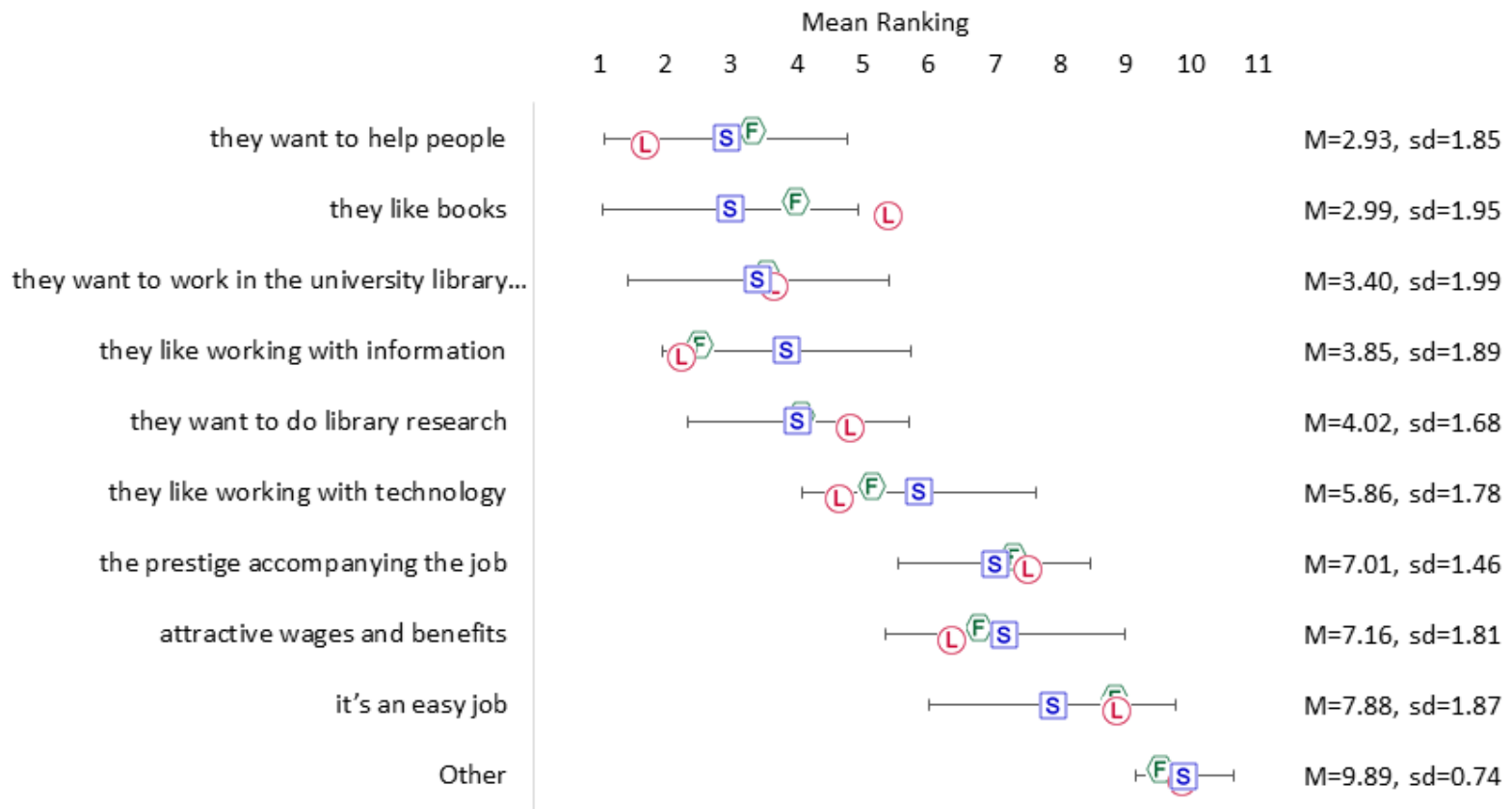

When Fagan (2003) asked this question, students' top two answers were the same but flipped: "they like books" was first, followed by "they want to help people" (p. 138). "They like working with technology" ranked \#4 (compared with the present study's \#6) and "They want to 
work in the university library environment" ranked \#6 (\#3 in this study). The group of last three answers was the same, with "It's an easy job" being the last-ranked response for both studies.

For the question set "Please read the following statements carefully and indicate your level of agreement" (Q22), if a respondent answered fewer than seven items, ${ }^{3}$ their response was excluded from analysis; thus, 217 responses were excluded $(n=235)$. After doing so, there were seven items that had one missing response each and two items with two missing responses each. Several items had more than 5\% "Not Sure" responses: "There is enough diversity (race, ethnicity, age, gender, etc.) among librarians" (18\%); “There are more female librarians than male librarians" (14\%); "Librarians use words that I don't understand" (7\%) of respondents; "Librarians are willing to change their services to meet patrons' needs" (6\%); and "I would be more willing to approach a librarian of my own race or ethnicity" (6\%). Not Sure responses were changed to Missing for the remainder of analysis.

Figure 12 shows student respondents' level of agreement with Q22's various motivational and affective statements about librarians. While a majority of librarians and faculty had chosen "Strongly Agree" for quite a few items, a majority of students only chose Strongly Agree for one item: "Librarians like helping students" (68\%). For an additional 15 items, students chose either Strongly Agree or Somewhat Agree. Similarly, there was no item where a majority of students chose "Strongly Disagree," although a majority of students chose either Strongly Disagree or Somewhat Disagree for five statements:

- Librarians use words that I don't understand

${ }^{3}$ This cutoff was chosen by examining missing response patterns. Since this series of questions was presented on 3 pages, it was clear some respondents stopped answering after the first page (perhaps due to survey fatigue). 
- Librarians like helping students with projects that are due tomorrow

- Librarians think people who don't know the basics about the library are stupid

- Librarians are too busy to help students

- Librarians are slow.

Figure 12. Student levels of agreement with motivational and affective statements (Q22).

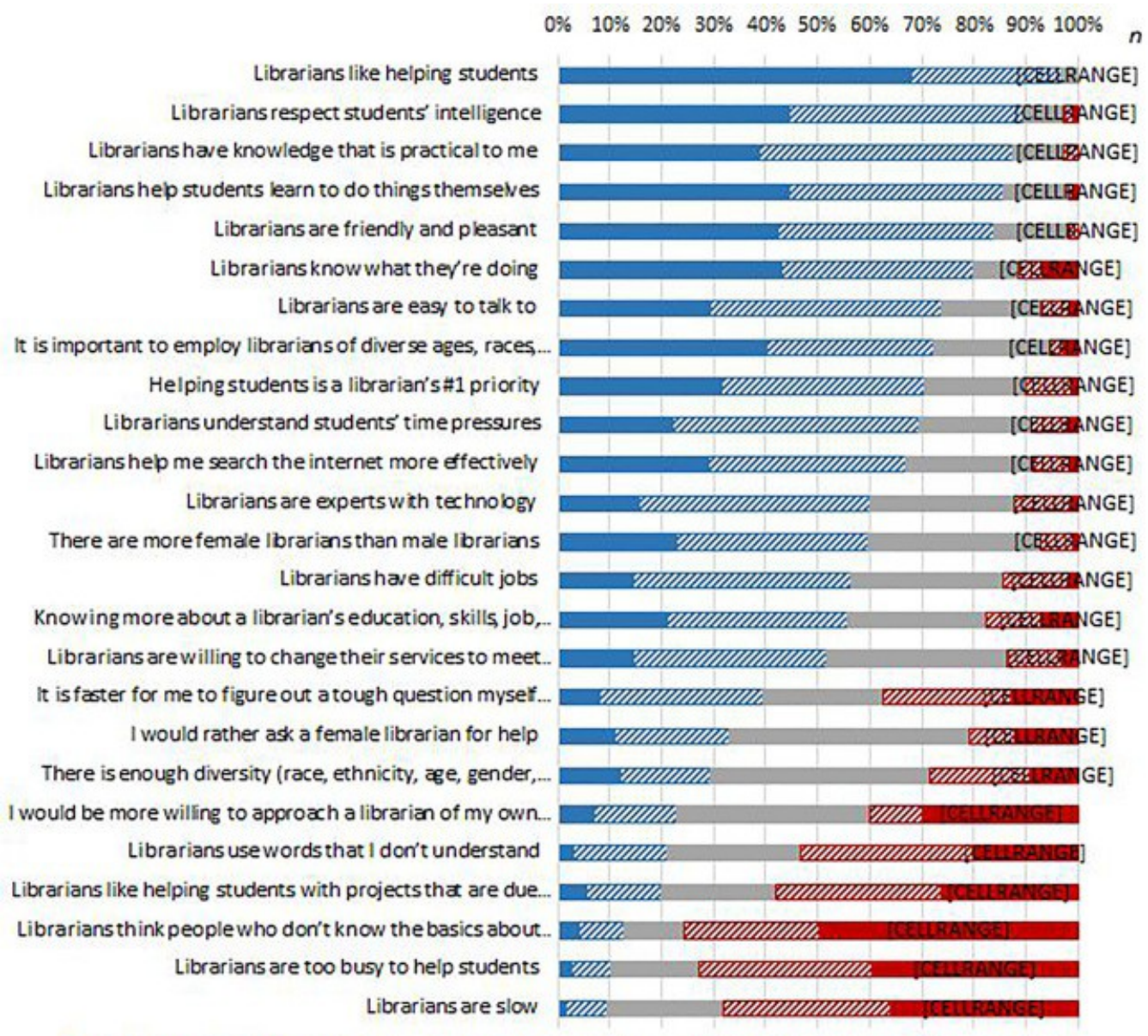

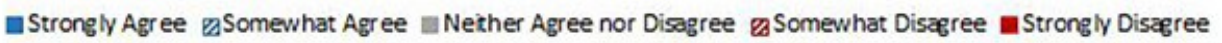

Note: See Appendix for full statements. Not Sure was a response option but was treated as missing data, which is not shown on chart. Sorted by total positive responses descending, then total negative responses ascending.

The items with the most responses to "Neither Agree nor Disagree" were "I would rather ask a female librarian for help" (42\%) and "There is enough diversity (race, ethnicity, age, gender, 
etc.) among librarians" $(42 \%)$, but recall that $18 \%$ of the sample answered, "Not Sure," suggesting $60 \%$ are not sure or neither agree nor disagree.

Figure 13 shows the largest gaps $(>=15 \%)$ between students and librarians on matching items in this set. A large majority of librarians (77\%) had agreed that librarians use words students don't understand. Only $21 \%$ of students agreed. In addition, while $100 \%$ of librarians thought knowing more about librarians would help students decide whether to ask for help, only $56 \%$ of students agreed. Students also believed it is faster for them to figure out a tough question themselves than did librarians (-28\% difference).

Figure 13. Differences between librarian, faculty, and student perceptions (Librarian Q10, $n=14-18$; Faculty Q17, $n=77-116$; Student Q22, $n=193-232$ ).

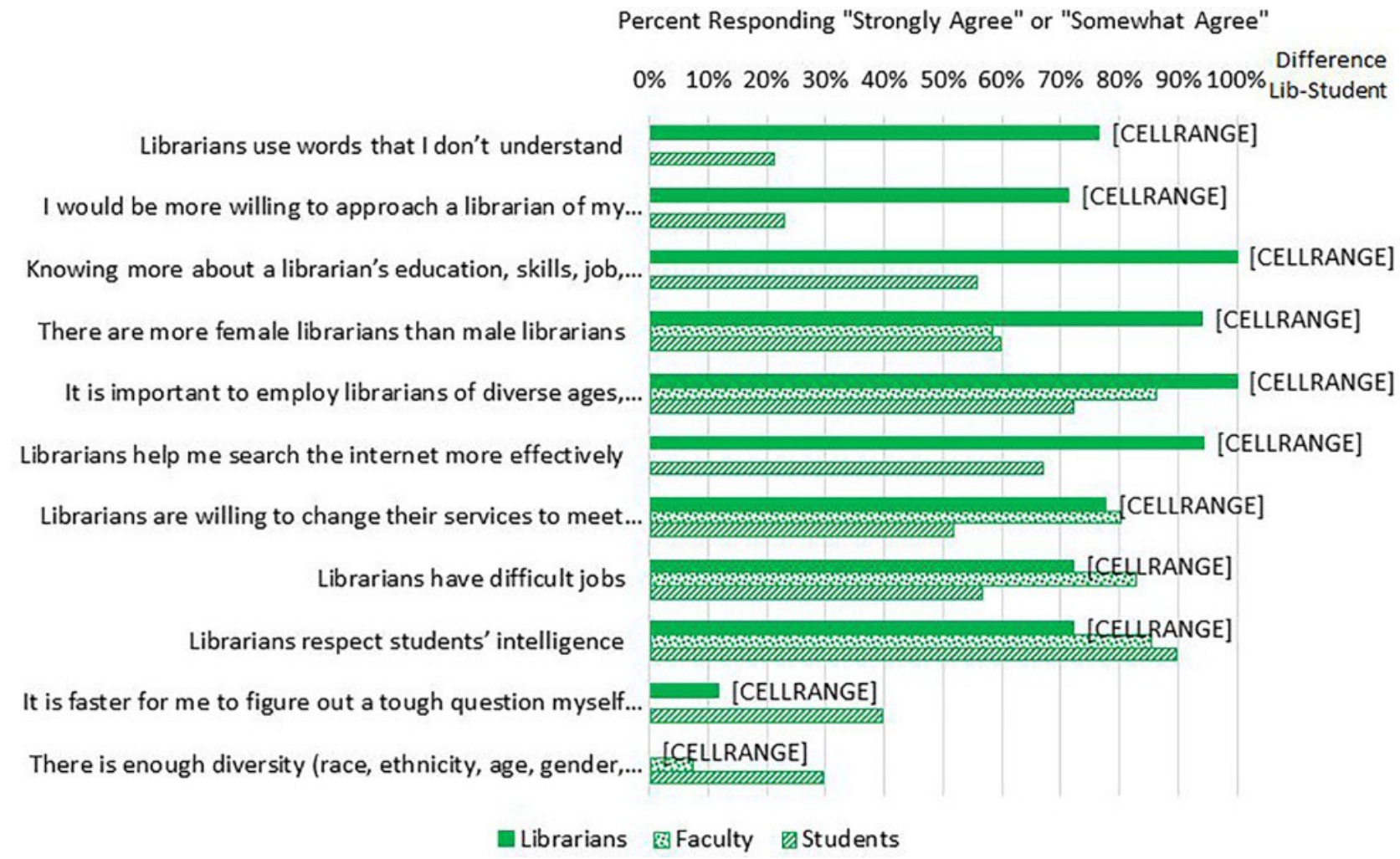

Note: Faculty data not available for some questions due to not asking the question the same way; no librarians agreed with "There is enough diversity..."

p. 30 
Students expressed less agreement than librarians that students would be more willing to approach a librarian of their own race or ethnicity or that it is important to employ librarians of diverse ages, races and genders. However, it is notable that a clear majority of students, faculty, and librarians agreed that employing librarians of diverse ages, races and genders is important, and that less than a third of students agreed there is enough diversity among librarians.

More moderate gaps exist between librarians and students with respect to "Librarians help me search the internet more effectively" (28\% difference), "Librarians are willing to change their services" (26\% difference), and "Librarians have difficult jobs" (16\% difference). Faculty, on the other hand, are closer to librarians on all these questions; in fact, faculty expressed slightly stronger agreement than did librarians concerning the latter two. Students were more confident that librarians' respect their intelligence than were librarians (-17\% difference).

Figure 14 highlights the major gaps between students who consult with librarians (“consulters") and students who hardly ever consult with librarians ("non-consulters"). Nonconsulters were almost twice as likely as consulters to believe librarians don't want to help with last-minute projects. Non-consulters were also less likely to find librarians easy to talk to; and were more confident than consulters in their own abilities to answer tough questions more quickly than librarians. Students generally didn't think of librarians as slow, but non-consulters were more likely to answer, "Neither agree nor disagree." They were less sure whether librarians use words they don't understand. However, consulters were more likely to perceive that librarians think people who don't know the basics of the library are stupid; $22 \%$ agreed with this 
statement compared to only $9 \%$ of non-consulters. ${ }^{4}$ Those who consult were more likely to agree that librarians know what they're doing, have difficult jobs, are friendly and pleasant, are experts with technology, and help them search the internet more effectively. They are also more likely to say it's important to employ librarians of diverse ages, races and genders. Non-consulters were generally less certain about these statements.

Figure 14. Gaps between students who consult with librarians and students who hardly ever consult with librarians (Q22, Consulters $n=57-58$, Non-Consulters $n=176-177)$.

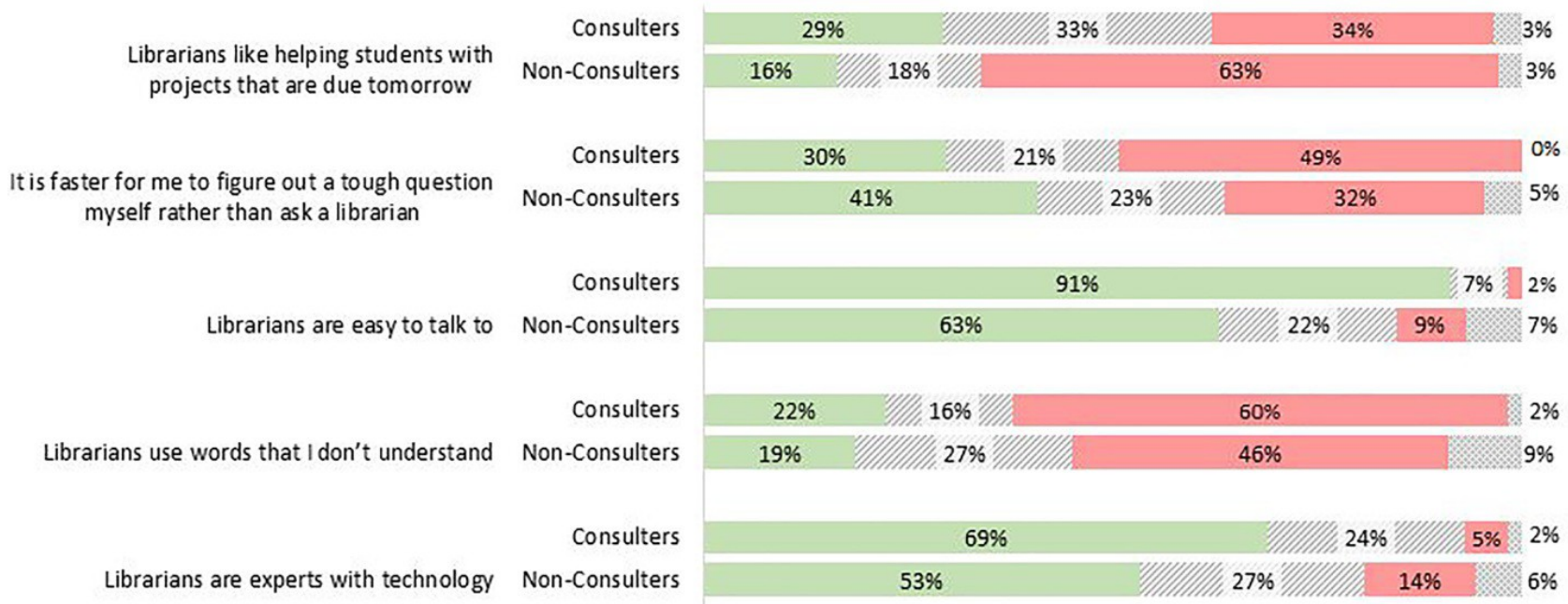

Item correlations for Q22 were examined visually to explore possible relationships among the affective items (listwise $n=144$ ). We observed 2 clusters but these did not map in any discernible way to the librarians' clusters and cannot be compared to the others due to differences in some items..

${ }^{4}$ These figures and the remaining findings in this paragraph are not included in Figure 14 as the gap was less than a $15 \%$ difference.

p. 32 
This study upholds the findings of Fagan (2003) and Bickely and Corrall (2011) that students have overall positive perceptions of librarian affect (the 1977 findings of Hernon and Pastine were to the contrary). Across the 1977, 2003, and present studies, librarians were perceived as helping students do things themselves. Along with Fagan and contrary to Hernon and Pastine, this study found students did not perceive librarians to be too busy to help them, nor did most think librarians viewed students as stupid. Rather, this study found students perceived librarians respect students' intelligence. The researchers discovered fewer students than Fagan acknowledging that librarians were faster at figuring out tough questions; however, it found more students to be confident that librarians understand students' time pressures. More students in this survey reported that having additional information about a librarian's background would help them decide whether to ask for help than previous studies.

Three hundred twenty-two students (71\%) responded to the question "Why don't you like to ask librarians questions?” (Q18) for a total of 406 coded references. Reasons given across responses were coded with the categories shown in Figure 15. Definitions for these categories are shown in Table 6 . Only categories associated with at least $3 \%$ of the total coded references are highlighted. 
Figure 15. Why students DON'T like to ask librarians questions $(Q 18$, Total

Respondents $=322$; Total coded references $=406 ;$ NCE $=$ Not Coded Elsewhere).

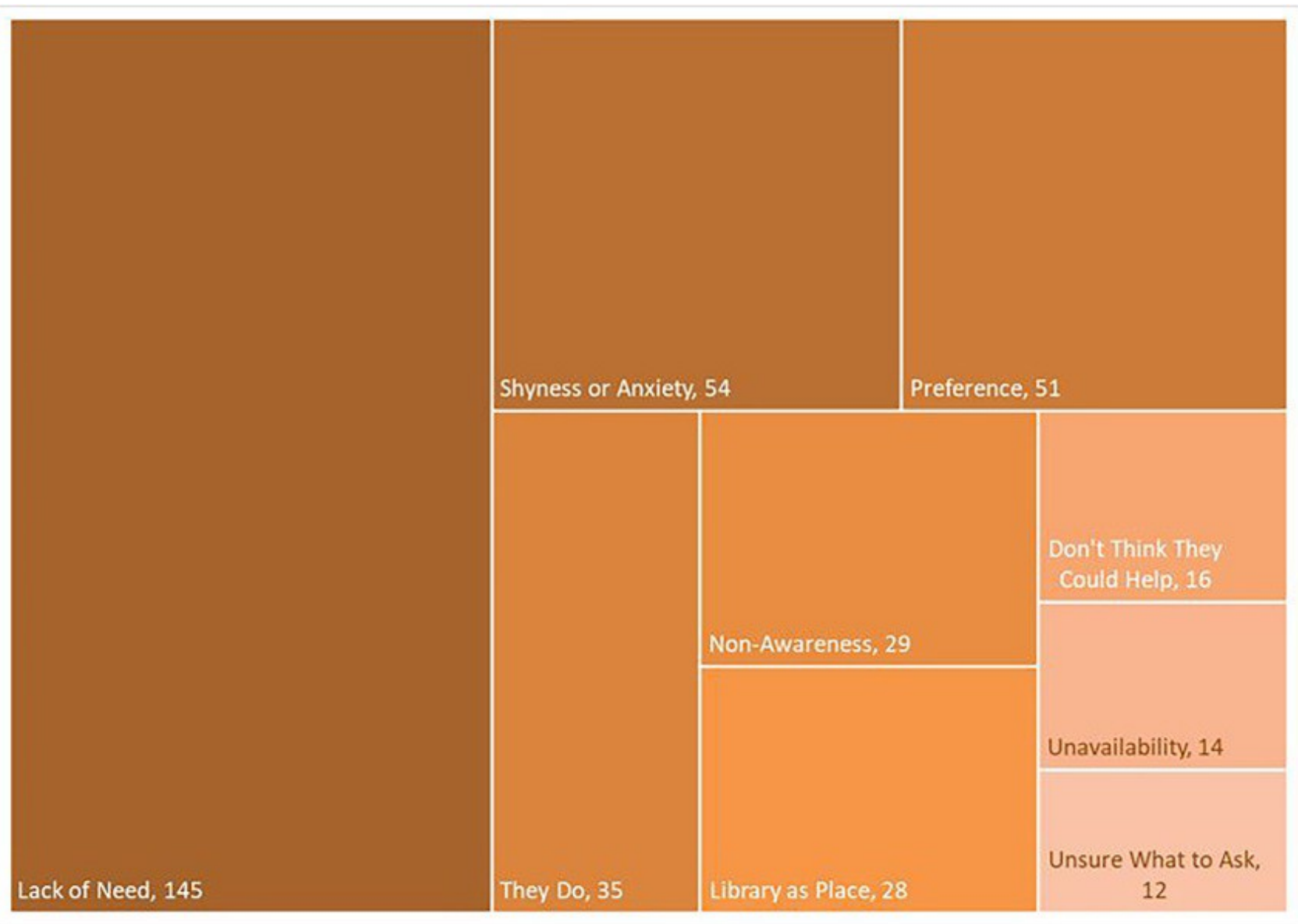

p. 34 
Table 6. Definitions for coding librarian responses to the question "Why might students NOT ask librarians questions?" and student responses to the question "Why don't you like to ask librarians questions?" (Librarian Q8, $n=14$; Student Q18, $n=322$ ).

\begin{tabular}{|c|c|c|c|}
\hline $\begin{array}{l}\text { Category / } \\
\text { Subcategory }\end{array}$ & Description & $\begin{array}{l}\text { Example responses in librarian } \\
\text { survey (Q8) }\end{array}$ & $\begin{array}{l}\text { Example responses in } \\
\text { student survey (Q18) }\end{array}$ \\
\hline Bad Experience & $\begin{array}{l}\text { Past experiences that were not } \\
\text { helpful or useful }\end{array}$ & $\begin{array}{l}\text { "Fear of librarians based on } \\
\text { school or public library } \\
\text { experiences" }\end{array}$ & $\begin{array}{l}\text { "Sometimes they come } \\
\text { off as stuck up" }\end{array}$ \\
\hline $\begin{array}{l}\text { Don't Think They } \\
\text { Could Help }\end{array}$ & $\begin{array}{l}\text { Assumptions that librarians would } \\
\text { not have the right expertise }\end{array}$ & $\mathrm{N} / \mathrm{A}$ & $\begin{array}{l}\text { "My work is too specific } \\
\text { for them to assist" }\end{array}$ \\
\hline Lack of Need & $\begin{array}{l}\text { Faculty feeling like they don't } \\
\text { need help }\end{array}$ & $\begin{array}{l}\text { "With so much information } \\
\text { available, students might feel like } \\
\text { they can find everything they } \\
\text { need on their own" }\end{array}$ & "I don't need help" \\
\hline Non-Awareness & $\begin{array}{l}\text { Not realizing that librarians could } \\
\text { help; distinct from being unsure } \\
\text { what to ask- }\end{array}$ & $\begin{array}{l}\text { "not knowing they have a } \\
\text { librarian" } \\
\text { "They don't understand we aren't } \\
\text { only about books." }\end{array}$ & $\begin{array}{l}\text { "Don't know who/where } \\
\text { they are" } \\
\text { "I do not know which } \\
\text { people are librarians" }\end{array}$ \\
\hline Preference & $\begin{array}{l}\text { Specific choices or inclinations } \\
\text { for getting help or information }\end{array}$ & $\begin{array}{l}\text { "They feel independent and don't } \\
\text { want to ask ANYBODY } \\
\text { questions" }\end{array}$ & $\begin{array}{l}\text { "I want to try to do it } \\
\text { myself" }\end{array}$ \\
\hline Shyness or Anxiety & $\begin{array}{l}\text { Emotional responses to asking for } \\
\text { help. Includes fear of looking } \\
\text { stupid, intimidation, } \\
\text { awkwardness, etc. }\end{array}$ & $\begin{array}{l}\text { "because they are ashamed or } \\
\text { embarrassed not to know" } \\
\text { "anxiety" }\end{array}$ & $\begin{array}{l}\text { "Afraid to sound dumb" } \\
\text { "Nervousness, social } \\
\text { awkwardness" }\end{array}$ \\
\hline They Do & $\begin{array}{l}\text { Rejections of the premise of the } \\
\text { question - they do like to ask } \\
\text { librarians questions }\end{array}$ & $\mathrm{N} / \mathrm{A}$ & $\begin{array}{l}\text { "I never mind asking } \\
\text { questions" }\end{array}$ \\
\hline $\begin{array}{l}\text { Time Constraints or } \\
\text { Too Busy } \\
\end{array}$ & Not enough time=- & $\mathrm{N} / \mathrm{A}$ & $\begin{array}{l}\text { "Often don't have the } \\
\text { time to meet with them" }\end{array}$ \\
\hline Unavailability & $\begin{array}{l}\text { Not being able to find librarians or } \\
\text { having difficulty contacting them; } \\
\text { distinct from not being aware that } \\
\text { librarians could help }\end{array}$ & $\begin{array}{l}\text { "We can't be available at all } \\
\text { hours" } \\
\text { "can't find a librarian" }\end{array}$ & $\begin{array}{l}\text { "They are normally not } \\
\text { there at night time" } \\
\text { "Couldn't find one" }\end{array}$ \\
\hline $\begin{array}{l}\text { Unsure What to } \\
\text { Ask }\end{array}$ & $\begin{array}{l}\text { Not knowing how to ask the right } \\
\text { questions to get the information } \\
\text { they are seeking; Distinct from } \\
\text { not being aware that } \\
\text { librarians could help }\end{array}$ & $\begin{array}{l}\text { "It may also be that the students } \\
\text { don't know what they can ask a } \\
\text { librarian." } \\
\text { "leading a busy, complicated life } \\
\text { and not aware of the range of } \\
\text { ways to ask librarians questions" }\end{array}$ & $\begin{array}{l}\text { "I don't know what } \\
\text { questions to ask" } \\
\text { "Not sure what to ask } \\
\text { them" }\end{array}$ \\
\hline
\end{tabular}

Note: Faculty were not asked how students might respond to this question.

The most common response was Lack of Need (145 mentions), including reasons such as: not being in the library, not having research assignments, not needing help because everything is online, and librarians not having the right expertise to help them. Two other frequently coded responses were Shyness or Anxiety (54 mentions) and Preference (51), both 
accounting for $13 \%$ of coded references. Example statements included "Afraid to sound dumb" and "Nervousness, social awkwardness." Responses indicated that some students have specific inclinations about getting help or information, including statements like "I want to try to do it myself."

Seven percent of mentions indicated that students were not aware of librarian services (e.g., "Don't know who/where they are"). The 28 mentions coded as Library as Place were almost always coded as "Lack of Need"" too. Comments referred to not going to the library building or not using the library building for a purpose involving librarians (Table 7). Students cited concerns that they wouldn't get the help they need (16 mentions), lack of availability of help (14), and being unsure what to ask (12), stating, "My work is too specific for them to assist," "They are normally not there at night time," and "I don't know what questions to ask." Only seven coded references indicated that a previous bad experience was a reason for not seeking help. Finally, 35 mentions $(9 \%)$ rejected the premise of the question; they said that they actually do ask librarians questions.

Table 7. Reasons students gave for not consulting with librarians that related to the library as a place.

\begin{tabular}{|l|l|}
\hline Sub-category & Examples \\
\hline Doesn't go to the library (15) & $\begin{array}{c}\text { "I don't often go to the library and because online } \\
\text { acted in public places." } \\
\text { "I typically don't use resources at the library so I have } \\
\text { ed for questions." }\end{array}$ \\
\hline $\begin{array}{l}\text { Goes to the library, but for a purpose } \\
\text { not requiring librarians (8) }\end{array}$ & $\begin{array}{c}\text { "I haven't been in the library before except to } \\
\text { "I don't typically need to ever find an actual book in the } \\
\text { "ibrary, just go there to do homework/study." } \\
\text { "I don't check out books, I use the library to study." } \\
\text { "I never know where the librarians are in the library." }\end{array}$ \\
\hline Other reasons (5) &
\end{tabular}


Hernon and Pastine found that students who don't ask for help "prefer to attempt to locate materials without librarian assistance" (1977, p. 134), and on a related note, reported that students "assumed all reference assistance given is either good or bad depending on the past assistance they received" (1977, p. 138), and that the preoccupied librarian was a barrier (p. 137). Fagan (2003) did not report students' responses to this question. Bickley and Corrall (2011) reported the most frequent reason for not "seeking help" was lack of need $(74 \%$ of those answering the question); only $8 \%$ reported reluctance based on poor prior experiences (p. 233).

Three hundred and thirteen (69\%) students responded to the question "Why do you like to ask librarians questions?” (Q19) for a total of 530 coded references. Reasons given were coded with eight broad categories, as presented in Figure 16. Only categories associated with at least $3 \%$ of the total coded references are highlighted. Definitions for these categories are shown in Table 8. 
Figure 16. Why students like to ask librarians questions (Q19, Total

Respondents $=313$; Total coded references $=530 ; \mathrm{NCE}=$ Not Coded Elsewhere).

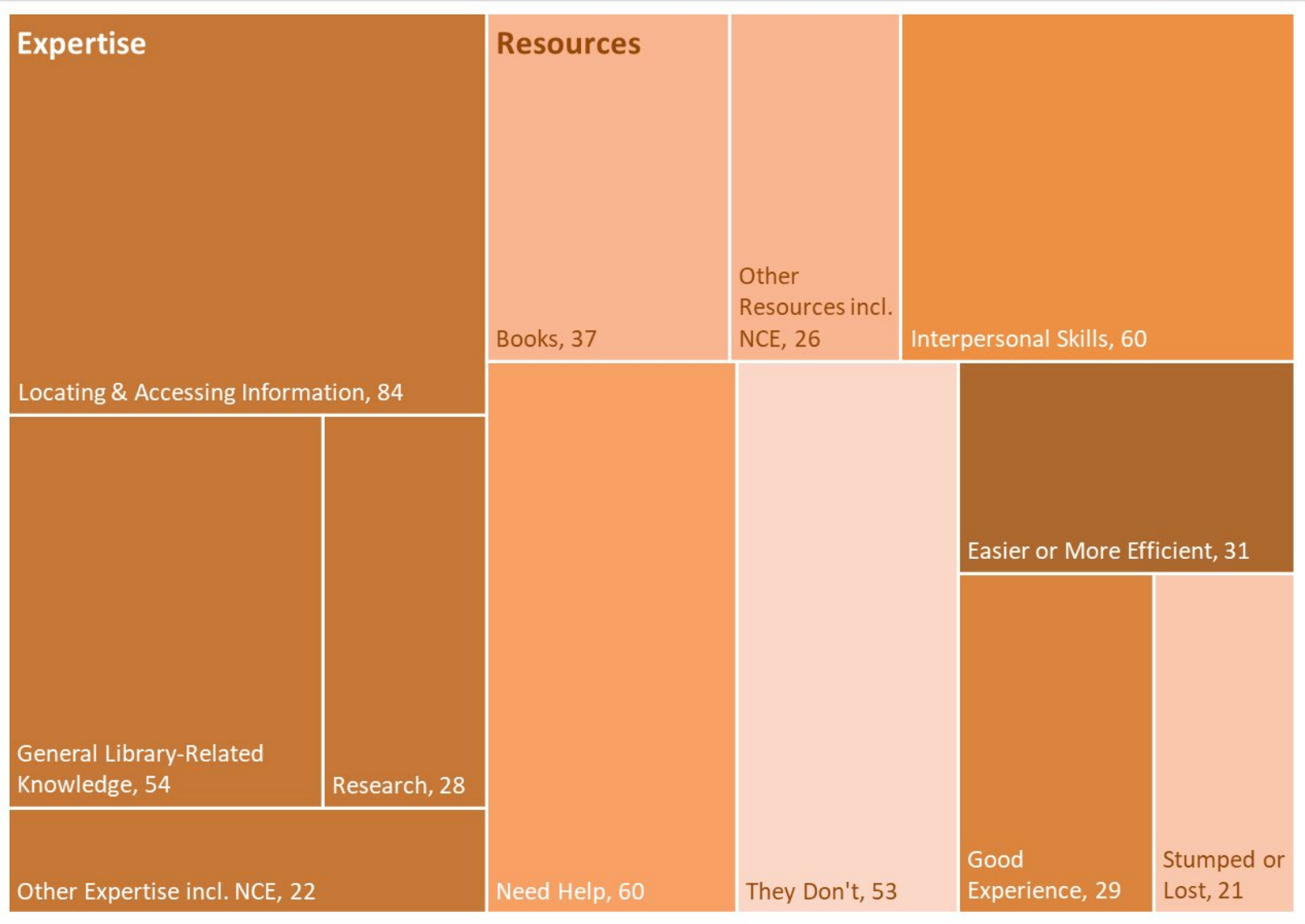

p. 38 
Table 8. Definitions for coding librarian responses to the question "Why might students ask librarians questions?" and student responses to the question "Why do you like to ask librarians questions?" (Librarian Q7, n=14; Student Q19, n=313).

\begin{tabular}{|c|c|c|c|}
\hline $\begin{array}{l}\text { Category / } \\
\text { Subcategory }\end{array}$ & Description & $\begin{array}{l}\text { Example responses in librarian } \\
\text { survey (Q7) }\end{array}$ & $\begin{array}{l}\text { Example responses in student survey } \\
\text { (Q19) }\end{array}$ \\
\hline $\begin{array}{l}\text { Assigned or Expected } \\
\text { To }\end{array}$ & $\begin{array}{l}\text { Interaction with librarians as part of an assignment } \\
\text { or expectation for a course }\end{array}$ & $\begin{array}{l}\text { "Written into the assignment" } \\
\text { "Because their professors tell them to" }\end{array}$ & "Professors" \\
\hline $\begin{array}{l}\text { Easier or More } \\
\text { Efficient }\end{array}$ & Saving time or effort & $\mathrm{N} / \mathrm{A}$ & $\begin{array}{l}\text { "They make finding resources easier" } \\
\text { "I can find the answer a lot faster" }\end{array}$ \\
\hline $\begin{array}{l}\text { Expertise / Evaluating } \\
\text { Information }\end{array}$ & $\begin{array}{l}\text { An ability to determine the quality of information } \\
\text { or sources }\end{array}$ & "They want the best sources possible" & $\begin{array}{l}\text { "Can help me find better resources than I } \\
\text { could find myself" }\end{array}$ \\
\hline $\begin{array}{l}\text { Expertise / General } \\
\text { Library-Related } \\
\text { Knowledge } \\
\end{array}$ & Librarians "knowing stuff" & $\mathrm{N} / \mathrm{A}$ & $\begin{array}{l}\text { "They know what they are doing" } \\
\text { "They know info I need" }\end{array}$ \\
\hline $\begin{array}{l}\text { Expertise / Information } \\
\text { Ethics }\end{array}$ & $\begin{array}{l}\text { nCopyright, intellectual property, author's rights, } \\
\text { citing, plagiarism, etc. }\end{array}$ & "Unsure how to cite something" & "I'm terrible at citations" \\
\hline $\begin{array}{l}\text { Expertise / Locating \& } \\
\text { Accessing } \\
\text { Information } \\
\end{array}$ & $\begin{array}{l}\text { Accessing or finding needed information; usually } \\
\text { also coded with a particular type of } \\
\text { resource (databases, books, articles, data, etc.) }\end{array}$ & "They need help finding information" & $\begin{array}{l}\text { "If I need to find something" } \\
\text { "They are always willing to help you with } \\
\text { finding materials" }\end{array}$ \\
\hline Expertise / Research & $\begin{array}{l}\text { Research used as a noun, adjective, or verb; } \\
\text { usually focused on processes-- }\end{array}$ & "Help formulating a research topic" & $\begin{array}{l}\text { "When I need help with research" } \\
\text { "I'm often confused when doing } \\
\text { research" }\end{array}$ \\
\hline $\begin{array}{l}\text { Expertise / Subject } \\
\text { Areas }\end{array}$ & $\begin{array}{l}\text { References either knowledge across many topics } \\
\text { (General Education expertise) or subject specialties } \\
\text { depending on position }\end{array}$ & $\mathrm{N} / \mathrm{A}$ & "When it is about research for my major" \\
\hline $\begin{array}{l}\text { Expertise / } \\
\text { Technology }\end{array}$ & $\begin{array}{l}\text { Computers, software, or technology } \\
\text { management skills }\end{array}$ & $\mathrm{N} / \mathrm{A}$ & "For technology questions" \\
\hline Good Experience & Past experiences that were helpful or useful & $\begin{array}{l}\text { "A librarian has been helpful to them in the } \\
\text { past" }\end{array}$ & $\begin{array}{l}\text { "In the past, they were helpful in helping } \\
\text { me find the right books for my research } \\
\text { papers in various subjects." } \\
\text { "They are always extremely helpful" }\end{array}$ \\
\hline Interpersonal Skills & $\begin{array}{l}\text { Communication skills, customer service skills, } \\
\text { social skills, or personal qualities such } \\
\text { as "patient" or "intelligent" }\end{array}$ & $\begin{array}{l}\text { "We are very helpful people and will go } \\
\text { out of our way to connect students with } \\
\text { what they need." }\end{array}$ & $\begin{array}{l}\text { "They're very friendly and helpful" } \\
\text { "They're nice" }\end{array}$ \\
\hline
\end{tabular}




\begin{tabular}{|c|c|c|c|}
\hline Need Help & A general need for information or assistance & $\begin{array}{l}\text { "Help knowing what they don't know } \\
\text { about a topic" }\end{array}$ & $\begin{array}{l}\text { "So I can get help" } \\
\text { "They might help me" }\end{array}$ \\
\hline Recommendation & $\begin{array}{l}\text { Receiving a recommendation from someone (e.g., } \\
\text { a peer or professor). Does not include references to } \\
\text { looking for a recommendation }\end{array}$ & $\begin{array}{l}\text { "If a professor or peer suggests asking a } \\
\text { librarian" }\end{array}$ & $\mathrm{N} / \mathrm{A}$ \\
\hline Resources & $\begin{array}{l}\text { Materials mentioned generically (holdings, } \\
\text { resources, stuff, etc.) or specifically (data, articles, } \\
\text { books, films, etc.); Includes the concept of } \\
\text { collection management. Often also coded at } \\
\text { expertise in locating/accessing information }\end{array}$ & "They need help finding resources" & $\begin{array}{l}\text { "To find a book" } \\
\text { "To check out materials" }\end{array}$ \\
\hline Stumped or Lost & $\begin{array}{l}\text { Being stuck or having no idea how to start; more } \\
\text { pointed than references to generally wanting or } \\
\text { needing help }\end{array}$ & "Unable to find anything on their topic" & $\begin{array}{l}\text { "I have no other option" } \\
\text { "I'm really stuck" }\end{array}$ \\
\hline They Don’t & $\begin{array}{l}\text { Rejections of the premise of the question - } \\
\text { they don't ask librarians questions }\end{array}$ & $\mathrm{N} / \mathrm{A}$ & $\begin{array}{l}\text { "I don't ask questions" } \\
\text { "I have never spoken to a librarian" }\end{array}$ \\
\hline
\end{tabular}

The most common reference was to librarians' Expertise (188 mentions), with many of those related to Locating \& Accessing Information (84 mentions) followed by General Library-Related Knowledge (54). Examples include "They are always willing to help you with finding materials" and "They know what they are doing." In contrast to Research dominating student perceptions of valuable Library Skills, only $9 \%$ of these coded references indicated Research as a reason to ask a question (28 mentions). Finally, the remaining categories were collated into Other Expertise, including NCE (22 mentions).

Additional reasons for why students like to ask librarians questions specified Resources (63 mentions) and Interpersonal Skills (60). Results suggest that students still associate librarians with access to books (37 mentions) over other resources like articles and journals (4). Social skills, or personal qualities such as "patient" or "intelligent," also were cited as reasons students sought help from a librarian (60 mentions) 
About $10 \%$ of coded references (53 mentions) rejected the premise that students seek librarian assistance ("I don’t ask questions" or "I have never spoken to a librarian"). But an almost equal percentage indicated that students ask questions because they do have a general need for information or assistance (60 mentions). Comments like "In the past, they were helpful in helping me find the right books for my research papers in various subjects" indicate that past encounters with librarians have been valuable (29 mentions). Finally, only $6 \%$ of mentions suggested that asking for help would be easier or more efficient; and $4 \%$ of mentions indicated that "being stuck" or "having no idea how to start" motivated students to ask questions. Categories that did not meet the 3\% threshold included Library as Place, Recommended, Assigned or Expected To, and NCE.

Twenty-four of the 452 respondents entered text into the "Any Additional Comments" box (Q23), but 16 of these were "no" or "N/A," indicating they had no comments. Three respondents had simple, positive comments: "Thanks," "Librarians are nice," and "I would love to work for the library"; one humorously commented, "where do you keep these librarians?" and one had a comment about the survey response options. One student wrote an anecdote where the person at the desk was unable to help, so the student found their own source instead, adding that librarians and their hours of availability should be better identified. Another student wrote that hiring the most qualified librarians is important, and that age, race, and gender should not be considered. Finally, a student who identified as a JMU Learning Centers employee wrote an appreciative note concerning librarians' expertise and assistance. 


\section{Discussion}

This section first discusses each results section in turn, then the themes emerging across all parts of the present study, with reflections on previous studies and the literature review. Next, the discussion examines the interplay of dynamics across the populations of librarians, faculty, and students at JMU. Finally, the authors present the limitations of this research and questions for further research.

\section{Librarians Helping Students Succeed}

This study's finding that $53 \%$ of students said librarians helped them succeed in college "at least a little" is similar to Fagan (2003, p. 136) and a marked improvement from 1977, when Hernon and Pastine wrote, "Many students stated that librarians had not played an important role in their college education ..." (p. 136). Furthermore, 74\% of students who consulted with librarians once per year or more in college said librarians helped them succeed at least "a moderate amount," which is encouraging.

\section{What Librarians Know}

Students' extemporaneous responses of what librarians learn in library school is impressive; they even identified some topics with more frequency than they did when considering what was valuable to themselves (e.g., technology, information ethics, literature, and subject area knowledge). For themselves, students most valued librarian expertise, especially in research, locating and accessing information, and general library knowledge. Interpersonal skills rivalled research and locating and accessing information in terms of importance. Mostly, students' responses about what is valuable to the university matched what is valuable to them, except for technology and teaching and pedagogy, which showed up a little more in the university context.

p. 42 
Students underestimated librarians' education and salary, as they have since 1977 (Fagan, 2003; Hernon \& Pastine, 1977; Luzius \& Noe, 2003). However, in contrast to Hernon and Pastine (1977), Jenkins (2001), and Fagan (2003), our respondents demonstrated more awareness of librarians as knowing not just how to locate and access, but how to use materials and do "proper" research. Critical thinking, writing, and teaching abilities also were mentioned. And (like Fagan, 2003), more than $85 \%$ of our students said librarians at JMU are faculty. Students' recognition that librarians at JMU have faculty status is supported by the language some used when describing skills librarians have that are valuable to the university (Q17). Four respondents specified that librarians help "other faculty" with research and projects and one stated that librarians have a "different perspective from other faculty" (emphasis added). This awareness might be institution-specific; fewer than half of Luzius and Noe's respondents identified librarians as faculty (2003, p. 14).

Although the results were encouraging in aggregate, this survey's results and the authors' experience suggest knowledge of librarians is highly variable. Practices such as branding what we create (e.g., tutorials) and creating videos for student populations (e.g. first-year students) about librarians' expertise could widen awareness.

\section{What Librarians Do}

Student perceptions of librarians' most frequent duties included both research and general help as well as clerical duties like shelving books (even though they are confident librarians are faculty) - librarians do it all! We suspect the increased efforts the JMU Libraries to engage students are paying off; students seem more aware of the variety of professional librarian duties and contributions to student success than was found in other studies (Bickley \& Corall, 2011; Fagan, 2003; Hernon \& Pastine, 1977; Polger \& Okamoto 2010). The idea of librarians cleaning 
the library is still fixed in some students' minds; however, they didn't think librarians work in Starbucks or provide support for campus wi-fi. Some common librarian activities seem hidden from students, such as publishing library research, evaluating student learning, creating online tutorials, and removing outdated books.

JMU students had some concept of librarians' teaching work; $89 \%$ of students said librarians Frequently or Sometimes teach research skills. This supports the literature review's finding that perceptions of librarians' teaching skills might be expanding (Fagan, et al., 2021). However, librarians' teaching of research skills emerged in student minds less prominently than it did for librarians or faculty (see Table 9). While librarians had ranked this duty as \#1 and 95\% said librarians did it Frequently, it was ranked $\# 8$ by students, and only $45 \%$ of students thought it was performed Frequently. (Faculty ranked it $\# 5$ and $64 \%$ responded Frequently). Students also didn't think to mention teaching in either of the open-ended questions about librarians' skills. However, both faculty and students thought librarians teach software skills and copyright principles more than librarians did.

Table 9. Comparison of librarian, faculty, and student responses concerning teaching and pedagogy duties (Librarian Q4, $n=20$; Faculty Q5, $n=123-126$; Student Q10, $n=427-435$ ).

\begin{tabular}{|l|l|l|l|l|l|l|}
\hline & $\begin{array}{l}\text { Librarian } \\
\text { Rank }\end{array}$ & $\begin{array}{l}\text { Librarian \% } \\
\text { Frequently }\end{array}$ & $\begin{array}{l}\text { Faculty } \\
\text { Rank }\end{array}$ & $\begin{array}{l}\text { Faculty \% } \\
\text { Frequently }\end{array}$ & $\begin{array}{l}\text { Student } \\
\text { Rank }\end{array}$ & $\begin{array}{l}\text { Student \% } \\
\text { Frequently }\end{array}$ \\
\hline $\begin{array}{l}\text { Teaching research } \\
\text { skills (in classes or } \\
\text { one-on-one) }\end{array}$ & 1 & $95 \%$ & 5 & $64 \%$ & 8 & $45 \%$ \\
\hline $\begin{array}{l}\text { Teaching copyright } \\
\text { principles (in } \\
\text { classes or one-on- } \\
\text { one) }\end{array}$ & 14 & $25 \%$ & 10 & $42 \%$ & 11 & $37 \%$ \\
\hline $\begin{array}{l}\text { Teaching software } \\
\text { skills (in classes or } \\
\text { one-on-one) }\end{array}$ & 17 & $15 \%$ & 15 & $25 \%$ & 15 & $30 \%$ \\
\hline $\begin{array}{l}\text { Evaluating student } \\
\text { learning }\end{array}$ & 13 & $35 \%$ & 17 & $15 \%$ & 23 & $23 \%$ \\
\hline
\end{tabular}


Note: "Rank" indicates the rank when sorted by total positive responses descending, then total negative responses ascending.

It is unclear whether it would be helpful for the average student to shed perceptions that librarians do clerical work, to know about librarians' less-visible duties, or to be more aware of librarians' teaching responsibilities. However, such enhancements to perceptions might do more to attract students to librarianship as a career.

\section{What Librarians Are Like}

As in Fagan's (2003) study, students perceived that librarians are there to help them, with "they want to help people" ranked as the top reason librarians became librarians. "Librarians like helping students" netted a majority of Strongly Agree responses, and about $70 \%$ of students agreed that helping students is one of librarians' priorities. More than $80 \%$ of students agreed that librarians respected their intelligence, have practical knowledge, help students learn to do things themselves, and are friendly and pleasant. Fagan (2003), Bickley \& Corall (2011), and Jameson, Natal \& Napp (2019) had also found large majorities of students describing librarians as approachable, a marked change from Hernon and Pastine's 1977 findings. It is encouraging to see that our profession has made such a change. Librarians don't see themselves as being at students' beck and call, however. Librarians disagreed vehemently with "Librarians like helping students with projects that are due tomorrow" (79\%), more than faculty (61\%) or students (58\%). This might indicate that librarians have greater understanding of the demands on their time from other job duties, as well as librarians' awareness of the advantages of gathering and analysing information iteratively.

At least at JMU, librarians likely don't need to spend energy investigating pop-culture librarian stereotypes - these didn't emerge among students in the open-ended questions. On the p. 45 
faculty survey, some respondents even expressed offense on behalf of librarians, because they found some of the survey's language insulting to librarians (Fagan, et al., 2020b).

Some of the most interesting findings of this study cross over multiple survey questions and were illuminated by the previous surveys of librarians and faculty; these will be discussed next.

\section{Most Students Don't Ask, Most Don't See a Need To (in College)}

A large majority of students don't ask to speak to librarians (Q12) and haven't consulted with librarians (Q7) during their college career. However, the percentage of students who ask (Q12, 29\%) is higher than some previous studies ( $8 \%$ in Fagan, 2003, p. 137; $11 \%$ in Hernon \& Pastine, 1977 p., 133), though not as high as Jameson, et al reported 49\% (2019, p. 373). A distinctive finding of our study is that a large majority of students said they consulted with their school's librarians in grade school, with $81 \%$ saying they consulted "Several times per year" or more. Even in middle school and high school, a majority— $73 \%$ and $61 \%$, respectively—said they consulted with their school's librarian at least several times per year. And, this study confirmed that students find JMU librarians highly approachable. So, why don't these former ask-ers ask at the university?

When JMU librarians were asked why they thought students would not like to ask librarians for help, the most frequent responses were that they believed students were unaware that librarians could help or were too shy or anxious to ask. While these were among students' responses, by far the most common student response was that they did not need the help that librarians could offer. This lack of need was a much less common response from librarians. Despite these clear differences, the two perspectives seem harmonious: Where students perceive 
a lack of need, librarians might argue students are not aware of how librarians can help. The differing frequency of responses coded as Non-Awareness supports this ( $28 \%$ for librarians, $8 \%$ for students), as we would not expect students to necessarily recognize what they do not know. Compared to Fagan (2003), this study found more students - 56\% compared to "about a third" (p. 141) — reporting that knowing more about a librarian's background would help them decide whether to ask for help.

Differences between student and librarian responses on the affective questions support this perceived lack of need / lack of awareness dichotomy. Students are confident about librarian terminology, and are less likely than librarians to agree that librarians can help them search the internet more effectively, or that it would be faster to ask a librarian than figure it out themselves. When students mentioned interpersonal skills as reasons not to ask questions, it was usually about the students themselves as individuals (e.g., shy, anxious) rather than assumptions about what librarians are like.

Fortunately, only $2 \%$ of student responses to "why don't you ask" cited a previous bad experience with a librarian. This aligns with Jameson, Natal, and Napp (2019), and contrasts with older studies $-11 \%$ of Bickley and Corall's students mentioned prior (bad) experiences as a reason they did not ask; and Hernon and Pastine (1977) found prior assumptions to be a strong influence. In keeping with those findings, our librarian sample overestimated how often a previous good experience would make students want to seek help from librarians $-11 \%$ of coded responses from librarians, $5 \%$ of coded responses from students.

While comparing responses on the duties question showed those who ask and those who don't ask have a similar sense of what librarians do, students' responses to why they would ask questions more commonly mentioned librarian expertise than social skills or personal qualities, p. 47 
suggesting that those who ask see librarian expertise as needed and relevant. Non-askers are aware of librarian duties but don't see the need. Conversely, of students who consult with librarians, 74\% credit librarians for helping them succeed at least "a moderate amount." However, it is unclear whether students consult because it helps them succeed, or whether successful students are more likely to be consulters.

In sum, these themes further highlight the importance at JMU of exploring more visible ways to show students how librarians' skills are relevant for their work. Given the findings related to books discussed in the next section, an emphasis might be librarians' online skills, online presence, and abilities with resources beyond books. Responses from students who ask could be translated into a marketing image targeted toward those who don't ask ("Here's why your peers ask us for help!"’).

Another takeaway might be for librarians to ease off on internalized pressure to evangelize non-question-askers. Such students might still feel librarians help them succeed. Among students who hardly ever consulted with a librarian, 16\% said that librarians helped them succeed at least "A moderate amount" during their college years, and if "A little" responses are included, the figure rises to $38 \% .^{5}$ This finding is not dissimilar to the finding of the faculty study that librarians are "key components of academic infrastructure" even if they did not avail themselves of librarian services (Fagan, et al., 2020b). There were 10 responses referring to student success across consulters and non-consulters; examples include "help JMU students reach their full academic potential," and "they have information to help students succeed." If this

${ }^{5} 26 \%$ of those who had consulted with librarians said "a moderate amount" or more, and if "A little" response are included, the figure rises to $33 \%$. Only 1 consulter was "Not sure" about their answer to this question, while $22 \%$ of non-consulters were "Not Sure."

p. 48 
concept is beginning to emerge in students' minds when they think of librarians that could inform library marketing. This suggests librarians should delve into the college student services literature —not just the library literature — to understand why students avoid seeking help and how to promote academic support services (Black, 2016).

\section{Our Brand Is Books, and that Brand Is Not Always What Students Buy}

Fagan (2003) noted student perceptions of librarians' knowledge as limited to the physical library, but also that students were becoming aware of librarians' role in assisting users with technology. However, in 2005, a major OCLC study found that books were entrenched as part of the library brand: more than $70 \%$ of youth aged 18-24 answered "books" as the first thing they thought of when thinking of a library (OCLC, p. 115). And in 2010, Polger and Okamoto were still finding that students perceive librarians' professional roles as "caretakers of books, reference assistants, and policy enforcers" (p. 26). In 2015, O'Neill and Guilfoyle's study of the reference department found that the assistance students most often sought was help finding books (p. 389). This study's findings continued to underscore students' association of librarians with books, across the entire survey.

Students ranked "they like books" as the $\# 2$ reason librarians chose their profession, much higher than librarians" average rank of \#6. On the question "What do you think academic librarians learn in their library classes?," students mentioned books 170 times across multiple categories, for example:

- "They learn about how to sort books and find them in the library."

- "How to monitor who needs to return books and at what time." 
- "Book organization; Websites to find books; How to promote more books than people need."

When examining the types of Resources mentioned across all open-ended survey responses, the connection between books and librarians becomes even more prominent. Among the 340 student mentions, books accounted for $70 \%$. Books were twice as frequently mentioned in the context of "valuable to students" as they were in the context of "valuable to the university." "Other Resources" were more likely to be mentioned than books in the context of valuable to the university_-perhaps because students are aware books are less relevant to modern libraries. In response to "Why don't you ask librarians questions," one student said, "Does anyone even check out books anymore? All those books kind of seem like a waste of money to me."

On the questions related to librarian duties, $96 \%$ of students said librarians lend books to users at least "Sometimes," and 89\% said that librarians sort and shelve books, in striking comparison to their responses to a question in the affective group: only $67 \%$ of students agreed that librarians help them search the internet effectively.

Students' association with books and the physical library also showed up in the question “Why don't you like to ask librarians questions?" (Q18). Many responses in the Lack of Need category specifically made a distinction between getting information online and how librarians might help (often associated with books). Students said, "Everything is online now instead of in books," "a lot of info is available online," and "I usually don't need to find books." Books were also a common theme in the responses to the converse question - "Why do you like to ask librarians questions?" (Q19). When books were mentioned in these responses, it was often in the context of librarians' ability to help students locate and access information, which was the 
"expertise" that students cited most often for this question (e.g., "To help me find books that might assist me on an assignment/research"). Overall, we see a trend of students saying they do not ask librarians questions because the students do not need books, and students saying they do ask librarians questions because librarians can help them find books. While this thinking does not represent a clear majority of responses, it does represent a plurality for both Q18 and Q19.

Given our students' history as consulters of public and school librarians, students' bookfocused views might stem from early literacy programming and outreach that are core aspects of services for children (American Association of School Librarians, 2013; Cerny, Markey, Williams \& Association for Library Service to Children, 2006). In addition, it struck us how many students named the Dewey Decimal System in the question about library school classes. Thirty-nine respondents mentioned the Dewey system, compared to only four mentions by faculty. Like most academic libraries, JMU uses Library of Congress Classification (LC) instead of Dewey, yet LC wasn't referenced in any student responses. While pondering this oddity, a Millennial colleague mentioned that students' familiarity with the Dewey system might be tied to a library-themed song from the cartoon series Arthur ("Library Card," n.d.; "Arthur: Library Song," n.d.), which has aired continuously in the United States since its debut in 1996 ("Arthur," n.d.).

The OCLC report hinted that libraries writ large should embrace their bookish brand, as it was associated with positive and comforting imagery for respondents (2005, p. 142). However, aggregated statistics from the Association of Research Libraries show that book circulation declined 68\% between 1998-2018 (Association of Research Libraries, n.d.); JMU's book circulation has decreased 66\% from 2012-2018 (Martin, R. D., personal communication [Report], July 15, 2020). Students arriving on college campuses are using print materials 
significantly less than previous cohorts; $12^{\text {th }}$ graders who reported reading a book or magazine every day declined from $60 \%$ in late 1972 to $16 \%$ in 2016 (Twenge, Martin, \& Spitzberg, 2019). Hence, books have become "glorified wallpaper" on most college campuses (Cohen, 2019). We know that in academic libraries, only certain disciplines are well-served by books, yet all disciplines benefit from librarians' skills with other resources and their expertise in information use. Strong mental linkages between librarians, books, and the physical library might be a barrier to identifying librarians as relevant allies in students' academic success. Future research could explore the effects of the pandemic on increasing the visibility of online information and on illuminating how librarians' roles transcend the physical domain.

\section{The Librarian-Faculty-Student Dynamic}

We identified several themes based on variations across the librarian, faculty, and student studies that have implications for practice (or for more research). Table 10 provides a summary.

\section{Table 10. Summary of findings: The librarian-faculty-student dynamic}

- While students valued librarians' expertise, it's less intense than the value librarians placed on their own expertise.

- Students and faculty valued librarians' skill with resources more than librarians did.

- Librarian, student, and faculty mental models of research are different and may affect their perceptions of librarians.

- Faculty were sometimes greater champions of librarians than librarians were of themselves.

- Faculty had far more accurate perceptions of librarians' association with books than did students.

- A majority of faculty consulted with librarians, while less than a third of students "ever ask to speak to a librarian.” 


\section{Clarifying Resources and Research for Students}

Students personally valued librarians' skills with Resources with greater intensity (19\% of mentions) than librarians did (9\%). And, students valued librarians' Expertise (50\% of mentions) with less intensity than librarians (61\%). Students also mentioned librarians' skills with Resources more frequently as valuable to the university (16\% of mentions) than librarians did (5\%), although faculty emphasized librarians' skills with Resources even more (21\%). Librarians might believe their expertise is of more value to students and might not be aware of the value students might place on librarians' knowledge of resources. An implication could be that everyone recognizes the nature of librarian expertise, but librarians are missing a marketing opportunity by not more fully engaging with the value students and faculty place on librarians' role as stewards of resources. As the faculty study stated, librarians might "downplay our expertise in Resources out of fear that faculty still value their campus library primarily as a 'dispensary of goods"” (Fagan, et al., 2020b) — but this fear might be unfounded. At JMU, our expertise seems recognized, and our marketing could safely focus a bit more on the Resources that have great appeal to our users.

Differences in librarian, faculty, and student mental models of research might affect comparison of perceptions. The ACRL Framework describes research as a "reflective discovery of information" which leads to the creation of new knowledge (Hosier, 2020, n.p.). But Kirker and Stonebraker (2019, p. 6) suggested librarians might have a more pragmatic definition: "library-based, information searching." First-year students might hear "research" and think about laboratory research (p. 7) or might focus on the production of a research product (Hosier, 2020, n.p.). Meanwhile, faculty might define research as "advancing knowledge" through peerreviewed journal articles or equivalent scholarly activities (Kellogg, 1987, p. 603) or as a 
"systematic investigation intended to develop or contribute to generalizable knowledge" (Office of Research Integrity, n.d.) — activities that might seem esoteric to undergraduates.

Why does a shared definition of research matter? Both Hernon and Pastine (1977) and Fagan (2003) stated in their overall conclusions that students saw librarians' roles primarily in finding information rather than in using information. This survey found evidence that some students associate librarians with "proper" research and value librarians for additional skills in working with information like critical thinking and writing. However, more students suggested they would seek out librarians for assistance with Locating \& Accessing Information (84 mentions) than for Research help (28). Librarians and faculty could do more to help students understand how research differs from locating and accessing information, not just to clarify perceptions, but also to encourage student to more confidently identify themselves as researchers.

Faculty: Our Not-So-Secret Champions - Can Faculty Help Educate Students?

In some ways, we found faculty to be greater champions of librarians than librarians were of themselves; they were more positive than librarians about the statements that librarians are experts with technology, are easy to talk to, respect students' intelligence, and have difficult jobs. And this study's findings showed faculty are fairly knowledgeable about what librarians do compared to students. For one thing, faculty had more diverse Resources linked in their minds to librarians —only $17 \%$ of faculty mentions of Resources referred to books, compared to $70 \%$ of student mentions.

Another gap between faculty and students relates to asking librarians questions: While only $29 \%$ of students ever asked to speak to a librarian, $63 \%$ of faculty did. The term 
"Reference" didn't emerge as a theme for either students or faculty. But the faculty study suggested that many activities underlying Reference are valued by faculty (Fagan, et al., 2020b). Students, on the other hand, talked about librarians' personal qualities more than communication skills. While faculty ask, students don't ask. So maybe students do need to understand more about librarians' Reference Skills—albeit without using that jargon.

JMU librarians already work closely with departmental faculty. Perhaps publishing something informal and easily digestible based on this study would help them see how they can support librarians' roles with their students. For example, faculty could work to clarify some of students' misperceptions or ignorance about librarians as they refer to the library in their syllabus or on assignments, specifically:

- Librarians are experts in information. Books are only one source of information; there is much, much more librarians can teach you.

- Librarians are experts in specialized information tools that will increase your academic prowess and impress internship advisers and employers.

- Librarians create research guides and online tutorials based on their valuable expertise in locating and accessing information.

- Librarians aren't only available in the physical library. They offer consultations via email, video conferencing, chat and in academic buildings across campus.

Faculty are well-positioned to clarify for students how to engage with librarians. But unless librarians highlight specific misperceptions such as the above, faculty might not be aware of students' specific knowledge gaps. 


\section{Limitations / Methodology Development}

Like previous studies, this inquiry tested the limits of student interest in librarians. Hernon and Pastine (1977) noted their respondents "had not previously thought about librarians" in the context of some questions (p. 136); and Fagan (2003) noted the popularity of blank answers and "Neither Agree nor Disagree" as a response. This study found similar ambivalence, with the sample size dropping from 452 to 235 as the survey wore long. It is unclear why the "extra-motivated" students persisted and to what extent that skews the responses. Among the students who persisted, "Somewhat Agree" was chosen on the affective questions more often than they chose "Strongly Agree" for 20 of the 25 items, indicating some ambivalence or uncertainty, perhaps because some students don't interact with librarians. This compares with 16 such items for faculty and 15 for librarians. This missing data further limits the generalizability of responses to the affective questions, even applied to JMU.

Many respondents were ambivalent about the race and gender of librarians. This might be due to JMU's majority White population, who are used to finding librarians of their own race. Since we did not ask a racial demographic question, we are unable to distinguish responses of people of colour, a major limitation of our research. The literature review suggests there are meaningful differences in library perceptions and experiences across populations (Fagan, et al., 2021).

Analysing student results confirmed the recommendations of the article on faculty perceptions to clarify questions about librarians being faculty at every university and whether people can tell who a librarian is (Fagan, et al., 2020b). And, the responses to the three "library school" and "valuable skills" questions uphold our previous recommendation to only ask "What 
knowledge, skills, and abilities do librarians have that is valuable to you, to the university, or both?" unless knowledge of library school is of particular interest.

It is also important to recall that our student sample was not statistically representative, so we do not generalize these findings to the JMU population. And, due to institutional differences, our findings cannot be generalized to other academic library populations.

\section{Future Research}

Students' memories of their public and school library consultations and their impressions of how librarians helped them succeed are intriguing. Would the observed trends be repeated if students were asked at the time of use? What are the forces that cause such trends? In what ways do students' experiences in K-12 and with public libraries influence their college library perceptions and experiences? Kracker and Pollio (2003) how undergraduates perceive libraries from preschool through college and showed that good early experiences affect later relationships with libraries and the need for more information literacy education at points of transition, such as the move from high school to college (2003). Their methodology has not been revisited in the professional literature — but perhaps it should be. Haras, Lopez, and Ferry's 2008 study of firstyear Latino undergraduates found a "positive relationship between research activity and library use throughout the K-12 years" (p. 431). Early library experiences were mentioned incidentally in Adkins and Hussey's interviews with Latino college students (2006) and Latham and Gross's studies of undergraduates' experiences with information literacy in K-12 education (2008), but this handful of studies does not adequately address this topic. Libraries have perhaps, as Kracker and Pollio noted in 2003, focused too much on studies like LibQUAL+ that measure users' perception of service quality rather than on how "first-person descriptions" illuminate the "human meaning of libraries and, on the basis of this understanding, to develop better and more 
useful procedures" (2003, p. 1104). With studies showing the precipitous decline in book and magazine readership among adolescents, it will be important to understand how future college students have perceived libraries throughout their educational journey.

Those interested in public services librarianship might wish to further explore how to encourage non-consulters to consult academic librarians, or to study the time of transition from middle school to high school to college: why do students' consultation behaviours change so much over these years?

Valuable research has been done on specific populations of library users. Especially as most libraries' demographics do not align with their user populations, research into the perceptions of subpopulations, especially underrepresented groups, should continue.

This study's findings revealed a large population of independent library users—students who don't consult with librarians. Yet, this population does seem to value librarians and libraries. How could library services be improved to address the needs of students who are independent by choice? How might this "librarian independence" play out differently in specific populations of students?

Space did not allow for a breakdown of differences by gender or academic discipline. Hernon and Pastine (1977) had found sex differences, but no disciplinary differences, in their study. While our findings might not be generalizable to the JMU population, analysis could inform hypotheses for future research. Also, while this study focused on perceptions of librarians, further analysis of this study's data might suggest future hypotheses concerning perceptions about libraries. 


\section{Conclusion}

These results upheld some findings of previous studies about perceptions of academic librarians. Although our student respondents demonstrated more awareness of librarians' professional duties, like our faculty respondents, they were still less aware of librarians' organizational duties. And, students were even less aware than faculty of the concept of “Reference." Librarians might need to accept that doing clerical work and low estimations of salary and degree requirements might continue among users. A cogent question is: Do such misperceptions limit strategic outcomes at a given institution? At JMU, misperceptions of salary and duties don't seem to be as critical to correct as some others.

Happily, pop-culture stereotypes of librarians were notably absent from both the faculty and student surveys, and both populations reported perceiving librarians as friendly and helpful. Both students and faculty respondents valued librarians' expertise and were able to identify many dimensions of that expertise. Students and faculty valued librarians' knowledge of resources and how to use them, even more than librarians do. The gaps among students, faculty, and librarians concerning what "research" is might impair clear communication as well as student identity development; thus, clarifying "research" seems like a valuable activity.

The nature of librarians' teaching was somewhat mysterious to students, and to a lesser extent, faculty. However, all agreed that librarians play an instructional role, and student and faculty perspectives on this role might be expanding. In contrast to JMU faculty, most students don't consult with librarians because they do not perceive they need what librarians' have to offer. This might be related to a strong association between libraries and books in students' minds, during times when books are declining in use. Educating students about librarians' diverse resource knowledge might help, but as previous studies also showed students don't ask, 
continuing to study student success with independent use of the library seems important.

Educating faculty concerning students' perceptions could also help faculty serve as allies in adjusting perceptions.

Future research into how school experiences play into perceptions of college librarians and libraries could inform library services for first-year students especially. Continued exploration of the perceptions of specific populations of students, especially concerning their success with libraries as independent users, seems valuable. Disciplinary differences also appear suitable for additional study. In conclusion, we advocate for a shift from broad analyses of perceptions such as this one to more targeted efforts that can further inform decision-making and practice.

\section{Disclosure Statement}

No potential conflicts of interest reported by the authors.

\section{References}

Adkins, D., \& Hussey, L. (2006). The library in the lives of Latino college students. The Library Quarterly, 76(4), 456-480. www.jstor.org/stable/10.1086/513862

American Association of School Librarians. (2013). Empowering learners: Guidelines for school library programs. Chicago, IL. American Library Association.

Arthur. (n.d.) IMDBtv. https://www.imdb.com/title/tt0169414/

Arthur: Library Song. (n.d.). PBS Kids. https://pbskids.org/video/arthur/3026258279

Association of Research Libraries. (n.d.). Service trends in ARL libraries 1998-2018. ARL

statistics survey statistical trends. https://www.arl.org/arl-statistics-survey-statistical$\underline{\text { trends/ }}$

p. 60 
Bickley, R., \& Corrall, S. (2011). Student perceptions of staff in the Information Commons: A survey at the University of Sheffield. Reference Services Review, 39(2). 223-243. https://doi.org/10.1108/00907321111135466

Black, S. (2016). Psychosocial reasons why patrons avoid seeking help from librarians: A literature review. The Reference Librarian, 57(1), 35-56. doi:10.1080/02763877.2015. 1096227

Cerny, R., Markey, P., Williams, A., \& Association for Library Service to Children. (2006). Outstanding library service to children: Putting the core competencies to work. Chicago, IL. American Library Association.

Cohen, D. (2019, May 26). The books of college libraries are turning into wallpaper. The Atlantic. https://www.theatlantic.com/ideas/archive/2019/05/college-students-arentchecking-out-books/590305/

Fagan, J. (2003). Students' perceptions of academic librarians. Reference Librarian, 37(78), 131-148. doi:10.1300/J120v37n78_09

Fagan, J. C., Ostermiller, H., Price, E., \& Sapp, L. (2020a). Librarian, faculty, and student perceptions of academic librarians: Study introduction and literature review. New Review of Academic Librarianship, 1-32. Advance online publication.

doi:10.1080/13614533.2019. 1691026

Fagan J.C., Ostermiller H., Price E. \& Sapp, L. (2020b). Academic librarian perceptions of academic librarians: Building a foundation of shared understanding, New Review of Academic Librarianship, 1-22. Advance online publication.

doi: $\underline{10.1080 / 13614533.2020 .1765817}$ 
Fagan J.C., Ostermiller H., Price E. \& Sapp, L. (2020c). Faculty Perceptions of academic librarians: Experts, connectors, and resource stewards. New Review of Academic Librarianship, 1-38. doi: 10.1080/13614533.2020.1819354

Haras, C., Lopez, E. M., \& Ferry, K. (2008). (Generation 1.5) Latino students and the library: A case study. The Journal of Academic Librarianship, 34(5), 425-433. https://doi.org/10.1016/j.acalib.2008.06.004

Hernon, P., \& Pastine, M. (1977). Student perceptions of academic librarians. College and Research Libraries, 38, 129-139. doi:10.5860/crl $38 \quad 02 \_129$

Hosier, A. (2020, February 12). Research is not a basic skill: Using the contextual nature of research to transform information literacy instruction [Presentation]. Carterette Series, Madison, WI. https://gla.georgialibraries.org/wpcontent/uploads/2020/02/events_carterette_research.pdf

Jameson, J., Natal, G., \& Napp, J. (2019). Evolving and enduring patterns surrounding student usage and perceptions of academic library reference services. College $\&$ Research Libraries, 80(3), 366-385.

Jenkins, S. (2001). Undergraduate perceptions of the reference collection and the reference librarian in an academic library. The Reference Librarian, 35(73), 229-241. doi:10.1300/ J120v35n73_01

Kellogg, R. (1987). Faculty members and academic librarians: Distinctive differences. College \& Research Libraries News, 48(10), 602-606. https://doi.org/10.5860/crln.48.10.602

Kirker, M. J. \& Stonebraker, I. (2019). Architects, renovators, builders, and fragmenters: A model for first year students' self-perceptions and perceptions of information literacy. 
The Journal of Academic Librarianship 45(1), 1-8.

https://doi.org/10.1016/j.acalib.2018.10.009

Kracker, J., \& Pollio, H. R. (2003). The experience of libraries across time: Thematic analysis of undergraduate recollections of library experiences. Journal of the American Society for Information Science and Technology, 54(12), 1104-1116.

https://doi.org/10.1002/asi.10309

Latham, D., \& Gross, M. (2008). Broken links: Undergraduates look back on their experiences with information literacy in K-12 education. School Library Media Research, 11, 1-16. https://eric.ed.gov/?id=EJ823031

Library Card. (n.d.). Arthur wiki. https://arthur.fandom.com/wiki/Library_Card

Luzius, J., \& Noe, N. (2003). Do they know who we are? Student perceptions of university librarians. Alabama Librarian, 53(2), 13-16.

OCLC. (2005). Perceptions of libraries and information resources. https://www.oclc.org/content/dam/oclc/reports/pdfs/Percept_all.pdf

Office of Research Integrity. (n.d.). Module 1: Introduction: What is research? https://ori.hhs.gov/module-1-introduction-what-research

O’Neill, K. L., \& Guilfoyle, B. A. (2015). Sign, sign, everywhere a sign: What does 'reference' mean to academic library users? The Journal of Academic Librarianship, 41(4), 386-393. doi:10.1016/j.acalib.2015.05.007

Polger, M. A., \& Okamoto, K. (2010). 'Can’t anyone be a teacher anyway?' Student perceptions of academic librarians as teachers. Library Philosophy \& Practice, 1-16.

Twenge, J. M., Martin, G. N., \& Spitzberg, B. H. (2019). Trends in U.S. adolescents' media use, 1976-2016: The rise of digital media, the decline of TV, and the (near) demise of 
print. Psychology of Popular Media Culture, 8(4), 329-345.

https://doi.org/10.1037/ppm0000203

p. 64 


\section{Appendix: Student Perceptions of Academic Librarians Survey Instrument}

IRB, protocol No. 17-0549

Note: for the purposes of this survey, the phrase "academic librarians" will refer to librarians who work in libraries at universities like James Madison University.

\section{You and your experience with librarians:}

1. I am a... -Selected Choice: First year (Freshman); Sophomore; Junior; Senior; Other

2. I identify as ... - Selected Choice: Female; Genderqueer or gender fluid; Male; Other [with optional text entry]; Prefer not to say

3. My major is within ... - Selected Choice: College of Arts \& Letters; College of Business; College of Education; College of Health \& Behavioral Studies; College of Integrated Science \& Engineering; College of Science \& Math; College of Visual \& Performing Arts; My major is undeclared

4. How often have you consulted librarians in a public library?

\begin{tabular}{|l|c|c|c|c|c|}
\hline & $\begin{array}{c}\text { More than } \\
\text { once a } \\
\text { month }\end{array}$ & $\begin{array}{c}\text { About } \\
\text { once a } \\
\text { month }\end{array}$ & $\begin{array}{c}\text { Several } \\
\text { times per } \\
\text { year }\end{array}$ & $\begin{array}{c}\text { Less than } \\
\text { once per } \\
\text { year }\end{array}$ & Never \\
\hline $\begin{array}{l}\text { During elementary } \\
\text { school (K-5)? }\end{array}$ & $\square$ & $\square$ & $\square$ & $\square$ & $\square$ \\
\hline $\begin{array}{l}\text { During middle } \\
\text { school (6-8)? }\end{array}$ & $\square$ & $\square$ & $\square$ & $\square$ & $\square$ \\
\hline $\begin{array}{l}\text { During high school } \\
\text { (9-12)? }\end{array}$ & $\square$ & $\square$ & $\square$ & $\square$ & $\square$ \\
\hline
\end{tabular}

5. How often did you consult your school's librarian?

\begin{tabular}{|l|c|c|c|c|c|c|}
\hline & $\begin{array}{c}\text { More } \\
\text { than once } \\
\text { a month }\end{array}$ & $\begin{array}{c}\text { About } \\
\text { once a } \\
\text { month }\end{array}$ & $\begin{array}{c}\text { Several } \\
\text { times per } \\
\text { year }\end{array}$ & $\begin{array}{c}\text { Less than } \\
\text { once per } \\
\text { year }\end{array}$ & Never & $\begin{array}{c}\text { My } \\
\text { school } \\
\text { didn't } \\
\text { have a } \\
\text { librarian }\end{array}$ \\
\hline $\begin{array}{l}\text { During } \\
\text { elementary } \\
\text { school (K-5)? }\end{array}$ & $\square$ & $\square$ & $\square$ & $\square$ & $\square$ & $\square$ \\
\hline $\begin{array}{l}\text { During middle } \\
\text { school (6-8)? }\end{array}$ & $\square$ & $\square$ & $\square$ & $\square$ & $\square$ & $\square$ \\
\hline
\end{tabular}




\begin{tabular}{|l|l|l|l|l|l|l|}
\hline $\begin{array}{l}\text { During high } \\
\text { school (9-12)? }\end{array}$ & $\square$ & $\square$ & $\square$ & $\square$ & $\square$ & $\square$ \\
\hline
\end{tabular}

6. To what extent, if any, do you think librarians helped you succeed?

\begin{tabular}{|l|c|c|c|c|c|}
\hline & $\begin{array}{c}\text { A great } \\
\text { deal }\end{array}$ & $\begin{array}{c}\text { A moderate } \\
\text { amount }\end{array}$ & A little & None at all & Not sure \\
\hline $\begin{array}{l}\text { During } \\
\text { elementary } \\
\text { school (K-5)? }\end{array}$ & $\square$ & $\square$ & $\square$ & $\square$ & $\square$ \\
\hline $\begin{array}{l}\text { During middle } \\
\text { school (6-8)? }\end{array}$ & $\square$ & $\square$ & $\square$ & $\square$ & $\square$ \\
\hline $\begin{array}{l}\text { During high } \\
\text { school (9-12)? }\end{array}$ & $\square$ & $\square$ & $\square$ & $\square$ & $\square$ \\
\hline
\end{tabular}

7. How often have you consulted academic librarians during your college years? -Selected Choice: More than once a month; About once a month; Several times per year; Less than once per year; Never

8. To what extent, if any, do you think librarians helped you succeed during your college education? -Selected Choice: A great deal; A lot; A moderate amount; A little; None at all; Not sure

\section{The librarian job:}

9. Please drag and drop the following reasons librarians chose to become librarians 1-9, where 1 is the top reason that librarians want to be librarians. You may write in another reason and rank it too.

- they want to work in the university library environment (scholarly, quiet, etc.)

- they like books

- attractive wages and benefits

- they want to do library research

- the prestige accompanying the job

- they want to help people

- they like working with information

- they like working with technology

- it's an easy job

- other

10. How often do you think academic librarians perform the following duties? Frequently; Sometimes; Rarely; Never; Not Sure 
- Issuing library cards

- Helping users to find books

- Lending books, films, equipment to users

- Processing fines

- Giving general directional help

- Buying books, journal and electronic materials

- Removing outdated books

- Creating Subject Guides

- Giving general help to students for research

- Giving subject-specific help to students for research

- Giving general help to faculty for research

- Sorting and putting books back on the shelves

- Evaluating student learning

- Creating online tutorials

- Repairing damaged materials

- Planning special events at the library

- Publishing research about the library profession

- Working in Starbucks

- Supporting library computers/printers/photocopiers

- Providing IT support for campus wi-fi

- Teaching research skills (in classes or one-on-one)

- Teaching software skills (in classes or one-on-one)

- Teaching copyright principles (in classes or one-on-one)

- Marketing library services and programs

- Analyzing the effectiveness of library services and programs

- Picking up trash/cleaning the library

11. In the JMU Libraries, can you tell which workers are librarians?

- Yes

- No

- Not sure

12. In the JMU Libraries, do you ever ask to speak to a librarian?

- Yes

- No

- Not sure

13. Do you think academic librarians are faculty at JMU??

- Yes

- No

- Not sure

14. Do you think academic librarians are faculty at every university?

- Yes

p. 67 
- No

- Not sure

15. How much do you think an entry-level JMU librarian makes per year?

- Less than $\$ 20,000$

- $\$ 20,000-\$ 29,999$

- $\$ 30,000$ - $\$ 39,999$

- $\$ 40,000-\$ 49,999$

- $\$ 50,000-\$ 59,999$

- $\$ 60,000-\$ 69,999$

- $\$ 70,000$ - $\$ 79,999$

- More than $\$ 80,000$

16. What skills do you think librarians have that are valuable to you? [multiline text entry box]

17. What skills do you think librarians have that are valuable to the university? [multiline text entry box]

18. Why don't you like to ask librarians questions? [multiline text entry box]

19. Why do you like to ask librarians questions? [multiline text entry box]

\section{Education:}

20. What do you think is the minimum level of educational qualifications required to be hired as an entry-level JMU librarian?

- High school degree

- Some college classes

- Bachelor's degree

- Master's degree

- More than one Master's degree

- Doctoral degree

- Multiple doctoral degrees

21. What do you think academic librarians learn in their library classes? Please write at least three topics you think are covered in library school classes: [multiline text entry box]

\section{General Opinions:}

22. Please read the following statements carefully and indicate your level of agreement. Remember, "Librarians" means academic librarians at a university like JMU:

Strongly agree; Somewhat agree; Neither agree nor disagree; Somewhat disagree; Strongly disagree, Not Sure 
- Librarians like helping students

- Librarians are slow

- Librarians like helping students with projects that are due tomorrow

- Librarians respect students' intelligence

- Librarians help students learn to do things themselves

- Librarians think people who don't know the basics about the library are stupid

- Librarians are too busy to help students

- It is faster for me to figure out a tough question myself rather than ask a librarian

- Librarians understand students' time pressures

- Librarians are easy to talk to

- Librarians are willing to change their services to meet patrons' needs

- Librarians use words that I don't understand

- Librarians know what they're doing

- Librarians have difficult jobs

- Helping students is a librarian's \#1 priority

- Librarians have knowledge that is practical to me

- Librarians are friendly and pleasant

- Librarians are experts with technology

- I would rather ask a female librarian for help

- Librarians help me search the internet more effectively

- Knowing more about a librarian's education, skills, job, and personality help me decide whether or not to ask them for help

- There are more female librarians than male librarians

- I would be more willing to approach a librarian of my own race or ethnicity

- There is enough diversity (race, ethnicity, age, gender, etc.) among librarians

- It is important to employ librarians of diverse ages, races, and gender

23. Any additional comments? [multiline text entry box] 